\title{
"SOOK CHING" 1942 DAN PENGLIBATAN SEKOLAH MENENGAH CHUNG LING PULAU PINANG: SUATU INTERPRETASI BARU
}

\section{"SOOK CHING" 1942 AND THE INVOLVEMENT OF CHUNG LING HIGH SCHOOL PENANG: A NEW INTERPRETATION}

\section{Tan Chee Seng}

School of Humanities, Universiti Sains Malaysia, MALAYSIA

Email: tancs@usm.my

Published online: 24 April 2019

To cite this article: Tan, C.S. 2019. "Sook Ching" 1942 dan penglibatan Sekolah Menengah Chung Ling Pulau Pinang: Suatu interpretasi baru. Kajian Malaysia 37(1): 51-82. https://doi.org/10.21315/ $\mathrm{km} 2019.37 .1 .3$

To link to this article: https://doi.org/10.21315/km2019.37.1.3

\begin{abstract}
ABSTRAK
Pada awal Zaman Pendudukan Jepun (1942-1945) di Tanah Melayu telah berlaku Operasi "Sook Ching" oleh pentadbiran tentera Jepun untuk menghapuskan orang Cina yang anti-Jepun. Operasi tersebut bermula di Singapura pada bulan Februari 1942 dan diperluaskan ke negeri-negeri Melayu, menjadikan Singapura sebagai tumpuan kajian sarjana berkaitan operasi tersebut. Pada hakikatnya, Operasi "Sook Ching” di Pulau Pinang terutamanya kes di Sekolah Menengah Chung Ling Pulau Pinang merupakan peristiwa tergempar di Tanah Melayu. Selain keunikannya sebagai sebuah sekolah Cina terkenal di Tanah Melayu, Chung Ling menjadi sasaran utama tentera Jepun disebabkan hubungan rapat warga sekolah dengan pihak Kuomintang (KMT) dan penglibatan aktif mereka menyokong China dalam Perang China-Jepun sejak tahun 1937. Kajian ini membincangkan perjalanan operasi tersebut pada tahun 1942 terutamanya pada 5 dan 6 April terhadap guru dan pelajar Chung Ling. Perbincangan ini disusuli dengan perbicaraan terhadap mereka yang bertanggungjawab dalam kes ini selepas kekalahan Jepun dan peringatan warga Chung Ling terhadap peristiwa tersebut. Artikel ini mengkaji latar belakang dan penglibatan aktif Chung Ling dalam aktiviti anti-Jepun yang menjadikan sekolah tersebut sebagai sasaran utama tentera Jepun sehingga melalui satu pengalaman paling ngeri dalam kalangan institusi pendidikan tempatan, dan merupakan kes paling ketara dalam Operasi "Sook Ching" bukan sahaja di Pulau Pinang, bahkan di Tanah Melayu. Hasil kajian ini diperoleh khususnya berdasarkan sumber bahasa Cina berkaitan Chung
\end{abstract}


Ling yang tidak ditemui daripada mana-mana sumber. Justeru artikel ini akan memberi suatu interpretasi baru dalam kajian "Sook Ching" yang memaparkan sebuah sekolah juga menerima kesan begitu ketara dalam operasi tersebut.

Kata kunci: "Sook Ching", Chung Ling, Pulau Pinang, Zaman Pendudukan Jepun, David Chen

\begin{abstract}
In the early Japanese Occupation in Malaya (1942-1945), the "Sook Ching" Operation was carried out by the Japanese military administration to eliminate the anti-Japanese Chinese. The operation started in Singapore in February 1942 and extended to the other Malay states, making Singapore the scholars' focal point in studying the operation. In fact, that "Sook Ching" Operation in Penang, especially the case of Chung Ling High School was a shocking event in Malaya. Besides the uniqueness of being the famous Chinese school in Malaya, Chung Ling was the main target of the Japanese army because of its close relationship with the Kuomintang (KMT) and the active involvement in supporting China in Sino-Japanese War since 1937. This study discusses the implementation of the operation in 1942, especially on 5 and 6 April upon the teachers and students of Chung Ling. This is followed by the trial of the people responsible for this case after the Japanese defeat and Chung Ling's remembrance of the incident. This article is about Chung Ling's background and active involvement in antiJapanese activities, making the school the main target of the Japanese military until the school faced the most horrifying experience among the local education institutions, and was notable for the "Sook Ching" Operation, not only in Pulau Pinang, but also in Malaya. This article which is based especially on the Chinese language sources related to Chung Ling that could not be found in other sources, will give a new interpretation of the "Sook Ching" research that portrays a school which was obviously affected by the operation.
\end{abstract}

Keywords: "Sook Ching", Chung Ling, Pulau Pinang, Japanese Occupation Period, David Chen

\title{
PENGENALAN
}

Salah satu bahagian dalam sejarah Malaysia yang tidak dinafikan beraneka warna dan mencabar intelek ialah Zaman Pendudukan Jepun (1942-1945) di Tanah Melayu. Kajian untuk melihat semula dan memperingati zaman tersebut tidak 
pernah terhenti, malah berterusan khasnya menjelang ulang tahun tamatnya zaman itu untuk setiap dekad. Lebih-lebih lagi, terdapat seruan untuk membangkitkan persoalan berkaitan perang (Perang Dunia Kedua) masih dicari dan belum diselesaikan. Misalnya, selepas 60 tahun tamatnya perang (zaman) itu, Cheah Boon Kheng berpendapat bahawa minat dan peringatan terhadap zaman tersebut masih menebal di mana:

In Malaysia there is no let-up in the people's interest on the World War II. The ghosts (read: memories) of the war are very much alive. Suffering, hardships, resistance, torture, horror and terror - these are the evergreen memories that the war calls up in the public imagination (Cheah 2007, 47).

Operasi "Sook Ching" merupakan salah satu episod pada zaman tersebut, memenuhi kriteria di atas, yang menyelubungi pelbagai persoalan yang menunggu jawapan, dan menimbulkan minat orang ramai sehingga masih diingati dengan aspek-aspek negatif seperti kesengsaraan dan penderitaan yang mewujudkan imaginasi awam.

Operasi "Sook Ching” atau dalam bahasa Cina Suqing (肃清) merupakan pelaksanaan pemeriksaan beramai-ramai (mass screening exercises) dan terjemahan secara harfiah ialah pembersihan atau penyingkiran (clearing or purging) (Chew dan Lim 1992, 1-2). Operasi ini juga dilihat sebagai operasi pembersihan (mopping-up operations/Operation Clean-up) atau bermaksud pembersihan melalui penghapusan (purification by elimination). ${ }^{1}$ Ooi Keat Gin merujuk "Sook Ching" sebagai pembunuhan beramai-ramai orang awam Cina secara sulit di kawasan pendudukan Jepun di Singapura dan di beberapa pusat bandar Malaya (Tanah Melayu), antaranya George Town, Pulau Pinang; Kuala Lumpur; Taiping, Perak; dan Johor Bahru dan Kota Tinggi di Johor. Sumber tentera Jepun melaporkan seramai 5,000 orang terbunuh ketika operasi ini berlaku di Singapura, dan menurut dakwaan sumber tempatan, secara keseluruhannya kira-kira 100,000 orang maut dalam operasi di Tanah Melayu (Ooi 2010, 3738). Operasi "Sook Ching" telah dimulakan di Singapura (Syonan) pada bulan Februari 1942 sebelum diperluaskan ke negeri-negeri Melayu. "Sook Ching" di Pulau Pinang, tidak kurang pentingnya terutama kes Sekolah Menengah Chung Ling pada bulan April 1942. Kes tersebut sememangnya merupakan peristiwa tergempar di Tanah Melayu, namun tidak dikaji dengan sebaik-baiknya setakat ini. Tumpuan kajian ini (Chung Ling) khususnya berdasarkan sumber-sumber daripada bahasa Cina berkaitan Chung Ling yang tidak ditemui dalam mana-mana sumber lain. 


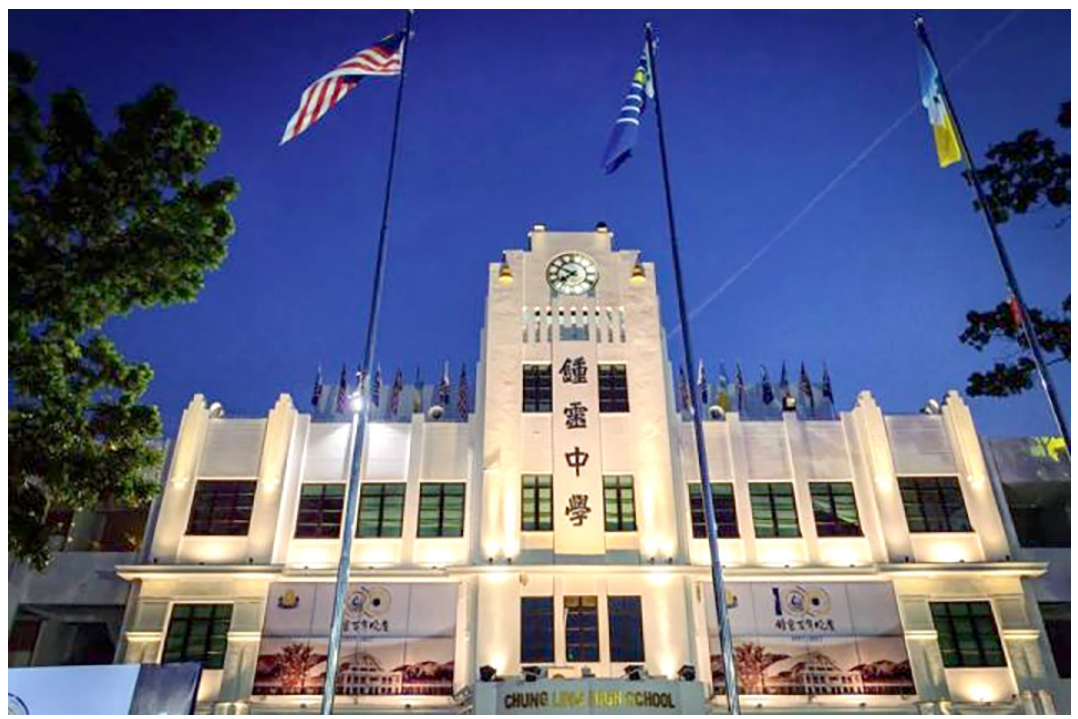

Rajah 1: Bangunan utama SMJK Chung Ling Pulau Pinang pada tahun 2017. Sumber: Penang Chung Ling High School-Board of Governors (n.d.)

\section{KAJIAN SEDIA ADA}

Seperti mana yang dikemukakan sebelum ini bahawa "Sook Ching" bermula di Singapura sebelum diperluaskan ke negeri-negeri Melayu yang lain. Hal ini telah menjadikan Singapura sebagai satu-satunya kes kajian atau tumpuan kajian apabila dikaitkan dengan Operasi "Sook Ching" (Wong 2017, 57; Chew dan Lim 1992). Malah, terdapat beberapa kajian tentang "Sook Ching" dan menjadikan kes Singapura sebagai tumpuan kajian atau topik utama perbincangan. Kajian tentang "Sook Ching" di negeri-negeri Melayu yang lain, sama ada dibincangkan dengan lebih lanjut, sepintas lalu atau sekadar menyebut diperluaskan ke negeri-negeri tersebut (Kratoska 1998, 95-100; Cheah 2012, 21-23; Ho 2009, 111-112; Kua 1999, 33). Terdapat juga kajian tertentu yang memfokuskan negeri-negeri Melayu yang lain seperti Kedah dan Johor. Maka, apabila "Sook Ching" dibangkitkan, kes di tempat kajian tersebut pula diberi penekanan (Mohamad Isa 1992, 102; Lim 2000, 144-145, 154). Tidak dinafikan, operasi "Sook Ching" di Singapura lebih diutamakan kerana operasi tersebut dimulakan di situ dan digambarkan oleh P. Lim Pui Huen sebagai yang "paling ganas" (most ferocious) (Lim 1995, 129).

Namun demikian, penelitian terhadap kajian tersebut yang menjadikan Singapura sebagai kajian utama berkaitan "Sook Ching" juga ada menyentuh tentang "Sook Ching" di Pulau Pinang seperti Paul H. Kratoska $(1998,99)$ dan Ho Hui Ling $(2009,112)$. Selepas kes di Singapura, Ho $(2009,112)$ telah menekankan 
operasi tersebut dijalankan secara besar-besaran di George Town pada 5 April 1942. Dalam kajian Ooi $(2010,28)$, beliau menjelaskan operasi "Sook Ching" berlaku di dua tempat iaitu George Town (Pulau Pinang) dan Singapura. Jika diteliti secara lebih mendalam huraian "Sook Ching" di Pulau Pinang, nama Sekolah Menengah Chung Ling Pulau Pinang diberi penekanan sebagaimana disebut oleh Paul H. Kratoska bahawa warga sekolah tersebut diberi "perhatian khas" (special attention) oleh pihak Jepun (Kratoska 1998, 99). ${ }^{2}$ Kajian Lim Beng Kooi tentang pendudukan Jepun di Pulau Pinang telah memfokuskan kepada Chung Ling di mana kebanyakan mangsa dalam "Sook Ching" di Pulau Pinang merupakan staf dan pelajar sekolah tersebut (Lim 1973/74, 11).

Justeru, kajian telah menunjukkan Chung Ling merupakan kes yang

paling ketara dalam Operasi "Sook Ching" di Pulau Pinang. Berbanding Singapura mahupun negeri-negeri Melayu yang lain, tidak ada sebuah sekolah atau institusi pendidikan yang begitu mendapat perhatian dan kerap dibangkitkan dalam kajian "Sook Ching". Hal ini menimbulkan satu persoalan iaitu mengapa sekolah tersebut menjadi satu-satunya sasaran sekolah bukan sahaja di Pulau Pinang, bahkan seluruh Tanah Melayu dalam Operasi "Sook Ching". Apakah keunikan sekolah ini, terutamanya yang dilakukan oleh warga sekolah sehingga pihak Jepun menumpukan perhatian kepadanya? Pada masa yang sama kajian ini akan membincangkan bagaimana latar belakang sejarah Chung Ling dan peranan sekolah tersebut semasa Zaman Pendudukan Jepun sehingga memberi kesan dalam Operasi "Sook Ching". Perbincangan awal dan usaha menjawab persoalan sedemikian bukan sahaja dapat menghubungkait perkara tersebut tetapi membantu kita memahami mengapa Chung Ling akhirnya menjadi sasaran dan mangsa utama dalam Operasi "Sook Ching" di Pulau Pinang sehingga meninggalkan kesan mendalam sehingga ke hari ini.

\section{LATAR BELAKANG SEJARAH CHUNG LING, 1917-1936}

Chung Ling diberi "perhatian khas" oleh pihak Jepun dalam Operasi "Sook Ching" yang sememangnya ada faktor-faktor terdekat yang akan dikupas dalam bahagian seterusnya (Keaktifan Chung Ling Menentang Jepun, 1937-1941). Namun, asalusul atau latar belakang sejarah sekolah sejak penubuhannya juga merupakan faktor-faktor lain yang menjadikan sekolah tersebut sebagai sasaran pihak Jepun. Asal-usul itu bukan sahaja menjadikannya unik tetapi menetapkan hala tuju dan peranan yang akan dimainkan dalam era menjelang Zaman Pendudukan Jepun.

Penubuhan Chung Ling pada asalnya dapat dihubungkaitkan dengan perkembangan politik di China sekitar Revolusi 1911. Perikatan Revolusioner (Tongmenghui 同盟会) yang merupakan badan politik pimpinan Sun Yat-sen pada masa itu telah menubuhkan cawangan Pulau Pinang pada tahun 1906, malah 
cawangan tersebut pernah menggantikan Singapura sebagai cawangan pusat di Asia Tenggara (Nanyang 南洋) pada tahun 1909 (Huang 2008, 182-184; Zhang 2004, 11-86). Setahun sebelum itu (1908), Kesatuan Filomatik Pulau Pinang (The Philomathic Union of Penang/Bincheng Yueshu Baoshe 槟城阅书报社) telah ditubuhkan oleh rakan seperjuangan Sun di Pulau Pinang. Penubuhan kesatuan tersebut adalah sejajar dengan arahan Sun untuk menjadikannya sebagai badan pelaksana dengan tujuan menyebarkan revolusi dan melaksanakan Tiga Prinsip Rakyat (Sanmin Zhuyi 三民主义) yang dicetuskan oleh Sun (Yang 1931， 6; Li 1939, A11). Dengan kata lain, Pulau Pinang merupakan salah satu pusat revolusioner yang penting di Asia Tenggara untuk Sun dan rakan seperjuangan menjelang Revolusi 1911.

Selepas Revolusi 1911, keadaan politik di China masih bergolak terutamanya Revolusi Kedua yang dilancarkan oleh Sun dan rakan seperjuangan pada tahun 1913 untuk menggulingkan Yuan Shikai (袁世凯) juga gagal (Suffian 2009, 105-113). Kegagalan Revolusi Kedua telah menimbulkan kesedaran golongan revolusioner yang berpandangan jauh di Pulau Pinang untuk mencapai persefahaman. Pemimpin-pemimpin Kesatuan Filomatik Pulau Pinang yang juga memegang keahlian Kuomintang (KMT, menggantikan Perikatan Revolusioner) berpandangan bahawa pendidikan kebangsaan hanya dapat dilakukan dengan cara penubuhan sekolah dan menerusi pendidikan untuk menjalankan kerja asas revolusi terutamanya pendidikan Tiga Prinsip Rakyat (Qi 1931, 157; Qi 1938, 1). Maka, para pemimpin iaitu Tan Sin Cheng (Chen Xinzheng 陈新政), Khaw Seng Lee (Xu Shengli 许生理), Khoo Beng Cheang (Qiu Mingchang 丘明昶), Chee Yong Aik (Xu Yangyi 徐洋溢), dan Lim Joo Teik (Lin Rude 林如德) juga berpendapat perlunya untuk mengasaskan sekolah yang berpegang kepada doktrin, dengan ini Sekolah Chung Ling ditubuhkan pada 9 Februari 1917 (Qi 1938, 1; Qi 1931, 157-158). Sekolah Chung Ling ditubuhkan pada peringkat sekolah rendah sahaja dan objektif sekolah berteraskan Tiga Prinsip Rakyat, malah lagu sekolah juga menegaskan doktrin tersebut. Sekolah tersebut pada mulanya menggunakan premis Kesatuan Filomatik Pulau Pinang di 19, Lebuh Melayu sebelum berpindah pada tahun yang sama ke premis berkongsi dengan kesatuan di 65, Jalan Macalister (Qi 1931, 158, 165). Jelasnya, sejak penubuhan Sekolah Chung Ling ia bukan sahaja dapat dihubungkaitkan dengan perkembangan di China, malah merupakan sekolah revolusioner yang berteraskan Tiga Prinsip Rakyat oleh Sun Yat-sen yang juga doktrin utama KMT. Kesatuan Filomatik Pulau Pinang yang menubuhkan Sekolah Chung Ling dan memberikan premis kesatuan untuk digunakan juga telah menunjukkan betapa eratnya hubungan sekolah dengan kesatuan itu. Pada masa yang sama, Kesatuan Filomatik Pulau Pinang yang dianggap sebagai badan revolusi Sun Yat-sen pernah mendaftar di bawah nama Sekolah Chung Ling untuk mengelakkan aset kesatuan disita oleh 
kerajaan penjajah British (Ye 2008, 24). Justeru, sekolah tersebut adalah naungan secara tidak langsung di bawah KMT menerusi Kesatuan Filomatik Pulau Pinang. Adalah tidak keterlaluan sekiranya Chung Ling dianggap sebagai sekolah KMT di Pulau Pinang.

Selain dikenali atas sifat kepartian KMT yang menebal, Sekolah Chung Ling juga terkenal dalam mempelopori penubuhan sekolah menengah Cina di Semenanjung Tanah Melayu. ${ }^{3}$ Selepas tahun 1921, para pemimpin Kesatuan Filomatik Pulau Pinang berasa terdesak untuk menyelesaikan masalah golongan yang tamat pelajaran di sekolah rendah tetapi tidak dapat meneruskan pelajaran di sekolah menengah, selain meningkatkan budaya Orang Cina Seberang Laut (Huaqiao 华侨) sejajar dengan perkembangan dunia dan memenuhi keperluan masyarakat. Berdasarkan kehendak ini, lahirlah Sekolah Menengah Chung Ling pada 20 Januari 1923 atas asas Sekolah Chung Ling dengan tertubuhnya kelas menengah rendah dan bahagian sekolah rendah masih dikekalkan (Chen 1939, A21-A22; Xu 1926, 1, 7). Sejak itu, Chung Ling telah menjadi sekolah menengah Cina pertama di Semenanjung Tanah Melayu yang masih kekal sehingga kini. Chung Ling juga memaparkan sifat pelopor di Semenanjung Tanah Melayu apabila menubuhkan kelas menengah atas pada tahun 1935 (Chen 2017, 15).

Sememangnya sifat pelopor Chung Ling tidak terhenti setakat ini sahaja, antaranya yang dikenali ramai ialah dasar dwibahasa (bahasa Cina dan bahasa Inggeris) sekolah dalam proses pengajaran dan pembelajarannya (Ye 2009, 26; Zheng 1999, 327-328; Nanyang Binglangyu Zhongling Zhongxuexiao 1926, 31-33; Wang 2017a, 155-174). Kemudian, dalam era pertama Pengetua Chung Ling David Chen (Chen Chongen 陈充恩) (1931-1939), selain dasar dwibahasa dimantapkan, perkara-perkara lain iaitu bangunan, infrastruktur, sistem pengajaran, kurikulum, ko-kurikulum, disiplin, sukan sekolah dan sebagainya juga ditingkatkan sehingga ada yang memaparkan sifat pelopor (Chen 2017, 13-16; Ye 2009, 41-65; Tan 1989, 68; Chen 1939, A23). Tidak hairan Tan Liok Ee menyifatkan "Chung Ling adalah pelopor dalam banyak perkara" (Chung Ling was a pioneer in many ways) (Tan 1997, 213). Kesemua usaha dan perkembangan tersebut telah menjadikan Chung Ling semakin terserlah dan mengatasi sekolah-sekolah Cina lain di Tanah Melayu dalam penerimaan elaun dan jumlah pelajar menjelang Zaman Pendudukan Jepun. ${ }^{4}$

Namun, satu aspek yang terserlah sejak David Chen menjadi Pengetua Chung Ling ialah hubungan sekolah yang semakin erat dengan KMT dan perkembangan politik di China. Hal ini sebenarnya berkait rapat dengan latar belakang David Chen. Chen yang berasal dari Nanjing China mempunyai semangat patriotisme yang kuat ke arah China. Chen merupakan penyokong setia KMT dan salah seorang pemimpin dalam Kesatuan Filomatik Pulau Pinang (Chen 1939, A23; Chen 2017, 12; Tan 1997, 93). Tan Liok Ee telah menggambarkan 
Chen sebagai seorang yang "meletak sekolah di barisan depan aktiviti nasionalis huaqiao dalam tahun 1930-an" (had kept his school in the forefront of huaqiao nationalistic activities in the 1930s) (Tan 1997, 213).

Semasa zaman Chen pada tahun 1930-an, selain majalah sekolah dimasukkan simbol parti KMT, misalnya foto Sun Yat-sen dan Chiang Kai-shek dalam versi tahun 1938, konsul KMT di Pulau Pinang kerap mengunjungi Chung Ling (Tan 1997, 213). Tambahan pula, Chen aktif melibatkan warga sekolah dalam sambutan dan hari peringatan yang dikaitkan dengan China dan KMT seperti Hari Kebangsaan Republik China (10 Oktober), Hari Kelahiran dan Hari Kematian Sun Yat-sen (12 November dan $12 \mathrm{Mac}$ ) yang bertujuan mewarisi semangat Sun Yat-sen atau secara tidak langsung KMT (Chen 2012, 142-156). Selain itu, warga Chung Ling pada permulaan sesi persekolahan 1937 telah menubuhkan Persatuan Galakan Gerakan Gaya Hidup Baru untuk memberi sambutan kepada Gerakan Gaya Hidup Baru yang dilancarkan oleh Chiang Kai-shek di Nanchang China sejak tahun 1934 (Suffian 2009, 157-158; Ye 2009, 48-49). Sebenarnya, tidak berapa lama selepas Chen menjadi Pengetua, Jepun telah mencerobohi Timur Laut China di Manchuria pada 18 September 1931. Sejak itu Chen memulakan gerakan anti-Jepun di sekolah dengan membangkitkan semangat warga sekolah memperingati peristiwa di China dan menghulurkan bantuan kewangan kepada tanah airnya. ${ }^{5}$ Malah, pelajar Chung Ling juga memaparkan keaktifan dalam protes pada tahun 1936 yang akhirnya juga dikaitkan dengan gerakan anti-Jepun (Ye 2009, 47). Apabila Jepun melancarkan serangan ke atas China melalui Insiden Jambatan Marco Polo pada 7 Julai 1937 yang mencetuskan Perang China-Jepun Kedua, usaha dan gerakan anti-Jepun sekolah Chung Ling telah ditingkatkan.

\section{KEAKTIFAN CHUNG LING MENENTANG JEPUN, 1937-1941}

Sejak Perang China-Jepun Kedua tercetus di China pada tahun 1937, gerakan anti-Jepun oleh orang Cina di Tanah Melayu menjadi semakin rancak di mana sumbangan dan penglibatan mereka dalam peperangan ditingkatkan. Antara tindakan masyarakat Cina tempatan ialah pemulauan barangan Jepun dan pengutipan derma bagimembantu pemimpinChina dalammenangkis pencerobohan Jepun di China. Sehubungan ini, Tabung Bantuan Perang Negara China (China Relief Fund) dan Pergerakan Tentera Pembebasan Nasional Nanyang (Nanyang National Salvation Movement) telah ditubuhkan untuk memberi bantuan kepada negara China dalam usaha menentang Jepun. Perhimpunan yang tetap dan aktiviti amal telah diadakan dalam masyarakat Cina di seluruh Tanah Melayu (Ho 2009, 111; Corfield dan Corfield 2012, 17). 


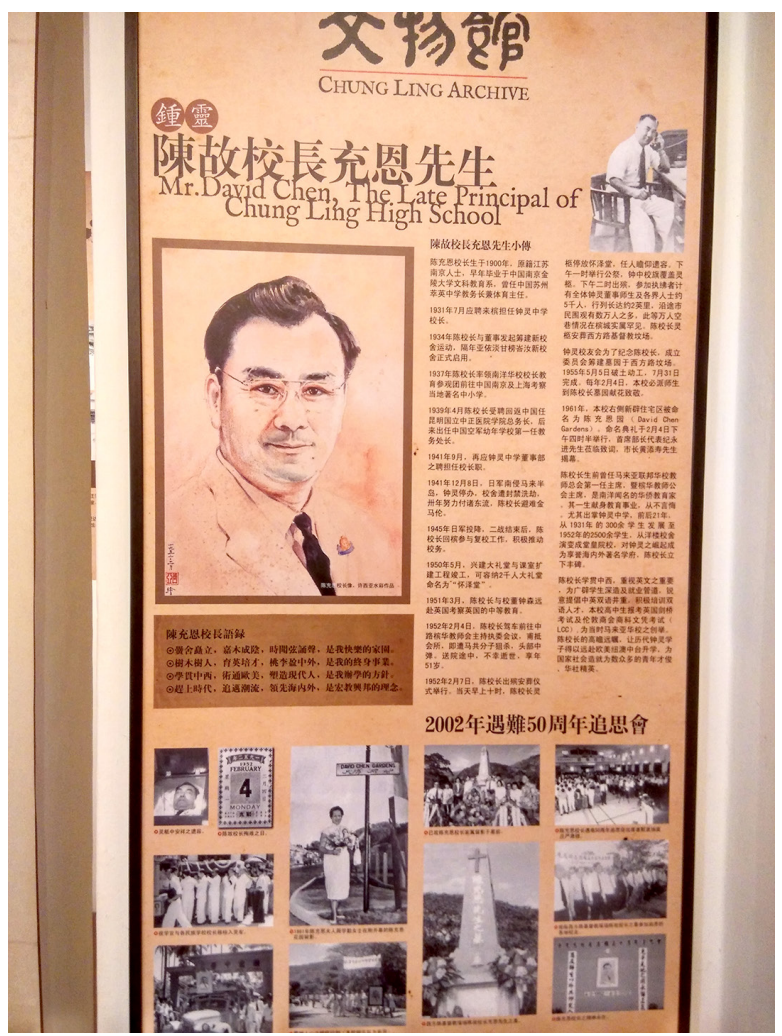

Rajah 2: Foto bekas Pengetua Chung Ling, David Chen dengan biografi ringkas dan foto lain berkaitan Chen pada tahun 1940-an-2000-an.

Sumber: Papan pameran Arkib Chung Ling (foto diambil oleh penulis pada tahun 2017).

Dalam suasana nasionalisme sedemikian, penglibatan setiap lapisan warga Chung Ling dalam gerakan anti-Jepun juga menjadi lebih rancak, malah agak terserlah dalam kalangan sekolah-sekolah Cina di Tanah Melayu. Seperti yang ditunjukkan pada latar belakang Chung Ling, ada pertindihan dalam pucuk kepimpinan Chung Ling dan Kesatuan Filomatik Pulau Pinang. Apabila Tabung Bantuan Perang Negara China Cawangan Pulau Pinang (Binhua Chouzhehui 槟 华筹赈会) ditubuhkan pada 18 Ogos 1937 oleh kesatuan tersebut, kepimpinan kesatuan yang juga ahli-ahli Jemaah Pengurus Chung Ling turut menerajui kepimpinan Tabung itu sehingga 1941 (Wang 2017b, 221-226, 299-301). Mereka bukan sahaja menderma sejumlah wang yang besar, tetapi berusaha menggerakkan pihak-pihak lain untuk turut serta dalam kempen pungutan dana di mana Chung Ling yang memulakan inisiatif ini. Ada sebahagian guru Chung Ling giat terlibat dalam Tabung tersebut. Pelajar Chung Ling pula melalui aturan sekolah akan bertugas membantu di ibu pejabat Tabung (Wang 2017b, 235-236, 240). Guru 
dan pelajar Chung Ling juga melancarkan gerakan pembelian bon Kerajaan Nasionalis China yang menjadikan wang derma Chung Ling sehingga tahun 1940 telah mengatasi sekolah-sekolah Cina yang lain (Chen 2017, 23-24; Wang 2017b, 234). ${ }^{6}$

Usaha warga Chung Ling tidak terhad setakat menderma sahaja, tetapi juga aktif terlibat dalam aktiviti yang dilancarkan oleh Tabung Bantuan Perang Negara China atau organisasi yang lain (Chen 2017, 24; Wang 2017b, 233-244). ${ }^{7}$ Pada masa yang sama, warga Chung Ling menerusi tiga sambutan dan hari peringatan yang pernah disebut sebelum itu: Hari Kebangsaan Republik China, Hari Kelahiran, dan Hari Kematian Sun Yat-sen, telah memasukkan dan mempergiatkan usaha derma atau aktiviti-aktiviti yang berkaitan (Chen 2012, 146, 152, 155-156). Pada tahun 1938, pelajar Chung Ling telah menyertai aktiviti pemulauan barangan Jepun dan penghapusan pengkhianat. Propaganda anti-Jepun juga disebarkan melalui Pasukan Belia Chung Ling (Chung Ling High School Youth Corps/Zhongzhong Qingnian Fuwutuan 锤中青年服务团) sejak tahun itu (Zhuang 1997, 79; Lim 1973/74, 11; Ye 2009, 56-57). Tidak kurang penting juga alumni Chung Ling melalui Persatuan Alumni Chung Ling berperanan dalam gerakan anti-Jepun. Hal ini dilakukan menerusi pendermaan terutamanya cara pertunjukan amal, pameran amal dan jualan amal, selain propaganda melalui majalah alumni (Wang 2017b, 244-247). Kepesatan aktiviti gerakan anti-Jepun telah menarik perhatian kerajaan penjajah British sehingga sekolah tersebut diberi amaran untuk ditutup. ${ }^{8}$

Selain itu, tidak dapat dinafikan gerakan anti-Jepun Chung Ling menonjol kerana usaha warga sekolah diperluaskan ke tanah air, di mana ada di antara guru dan pelajar Chung Ling telah kembali ke China untuk mempertahankan tanah air mereka daripada pencerobohan Jepun. Mereka sama ada terlibat dalam misi ketenteraan atau tugas-tugas lain yang berkaitan gerakan anti-Jepun. Namun, misi ketenteraan yang mereka sertai bukan sahaja dengan Kerajaan Nasionalis atau KMT sahaja. Sebahagiannya menyertai komunis atau Parti Komunis China (PKC) dan ada di antara mereka telah terkorban dalam misi tersebut (Chen 2017, 24-25; Wang 2017b, 247-248). ${ }^{9}$

Kemuncak penglibatan warga Chung Ling di China ialah apabila Pengetua David Chen sanggup meletakkan jawatan pada 20 September 1939 dan kembali ke Kunming (昆明), China untuk berkhidmat dengan Kerajaan Nasionalis. Chen telah membawa bersama guru Qian Jingcheng (钱景澄) dan 14 pelajar Chung Ling yang akan melanjutkan pelajaran di China termasuk ada antara mereka yang memasuki sekolah tentera (Wang 2017b, 252-253). ${ }^{10}$ Chung Ling kemudian diketuai Lim Hooi Seong (Lin Huixiang 林惠祥) untuk satu jangka masa yang pendek (1939-1941). Namun demikian, gerakan anti-Jepun tidak terbantut tetapi berterusan. Sebagai contoh, dalam Majalah Bulanan Chung Ling (Zhongling Yuekan 锤灵月刊) yang dimulakan di bawah inisiatif Lim, 
telah dilaporkan pungutan dana masih berjalan sehingga salah satu pungutan adalah tertinggi antara sekolah-sekolah Cina di Tanah Melayu dengan mencapai hampir empat ribu Dolar Selat. Lim juga berbangga dengan pelajar lepasan Chung Ling yang mendapat pengajaran kedua-dua tahap sekolah Cina dan Inggeris sehingga mereka setanding dengan pelajar lepasan sekolah di negara China dan kembali berkhidmat dengan tanah air (Lin 1940, 5). Lim telah meninggalkan Chung Ling pada 1 April 1941 dan David Chen telah dijemput kembali oleh Jemaah Pengurus Chung Ling untuk memimpin Chung Ling pada 26 September. Guru Qian Jingcheng juga mengikut jejak langkah Chen untuk kembali berkhidmat (Wang 2017b, 253). Pada masa David Chen kembali ke Chung Ling, ia merupakan waktu genting menjelang meletusnya Perang Pasifik.

\section{"SOOK CHING" DI CHUNG LING}

Tentera Jepun telah memulakan penaklukan ke Tanah Melayu apabila mendarat serentak di Singgora dan Patani, Thailand serta Kota Bharu, Kelantan pada 8 Disember 1941. Hari tersebut merupakan hari pertama peperiksaan semester di Chung Ling dan kali terakhir perhimpunan sekolah sebelum pendudukan Jepun. Dalam kemaraan tentera Jepun di Tanah Melayu, bandar George Town telah diserang dengan hebat oleh pesawat pengebom tentera Jepun mulai 11 Disember 1941 yang membawa kepada sekitar 2,000 orang terkorban atau cedera pada hari tersebut. Sebenarnya, pada pagi 11 Disember sebelum berlakunya pengeboman, mesyuarat terakhir guru dan staf Chung Ling telah diadakan. Walau bagaimanapun, satu perjumpaan tergempar telah diadakan di rumah guru Wang Shiyi (王世毅) yang memutuskan Pengetua David Chen perlu meninggalkan Pulau Pinang atas statusnya sebagai pemimpin kepada Chung Ling yang akan menjadi sasaran Jepun dan rekod Chen yang pernah berkhidmat di China. Pada 12 Disember Chen terpaksa meninggalkan Pulau Pinang secara bersendirian dan akhirnya bersembunyi di Tanah Tinggi Cameron sepanjang Zaman Pendudukan Jepun. Seterusnya, bagi menghentikan pengeboman Jepun, setiap rumah dan kedai di Pulau Pinang telah mengibarkan bendera putih pada 15 Disember sebagai tanda menyerah kalah, kecuali Chung Ling yang enggan mengikutinya. Tentera Jepun kemudian telah mendarat di Pulau Pinang pada 18 Disember dan menaklukinya pada hari berikutnya (Ho 2009, 109; Corfield dan Corfield 2012, 208-209, 243, 246; Wang Y. 1947, 24-25; Chen 2003, 206-208).

Selepas kejatuhan Singapura ke tangan tentera Jepun pada 15 Februari 1942, seluruh Tanah Melayu telah berada di bawah cengkaman Jepun. Operasi "Sook Ching" pun bermula di Singapura berikutan Ibu Pejabat Tentera ke-25 mengeluarkan perintah pada 17 Februari dan pasukan Kempeitai (polis tentera Jepun) telah melaksanakannya sejak 21 Februari. Operasi itu kemudian 
diperluaskan ke negeri-negeri Melayu yang lain sejak awal bulan Mac (Cheah 2012, 21-23). Kajian Cheah Boon Kheng telah menunjukkan melalui "Sook Ching", antara tiga kaum utama di Tanah Melayu, kaum Cina merupakan kaum yang paling dianiayai dan ditindas oleh orang Jepun kerana mereka mempunyai sentimen anti-Jepun dan penentangan yang kuat sebelum dan semasa perang (Cheah 2000, 28).${ }^{11}$ Menurut Ooi Keat Gin, tentera Jepun mempercayai anasir anti-Jepun ada dalam kalangan masyarakat Cina berdasarkan kegiatan-kegiatan praperang komuniti tersebut. Antara kegiatan tersebut ialah orang Cina Seberang Laut di Asia Tenggara mengatur satu siri aktiviti Tabung Bantuan China antara tahun 1938-1942, dan sukarelawan Cina kembali ke tanah air memberi sumbangan dalam usaha perang menentang Jepun (Ooi 2010, 38). Sememangnya tentera Jepun bertindak ganas terhadap masyarakat Cina untuk mengekalkan keamanan kerana takutkan penentangan gerila secara bersenjata yang dilancarkan oleh orang Cina. Golongan Cina yang menjadi mangsa ialah penyokong aktif KMT, penyokong komunis terutamanya suku Hainan, ahli pasukan sukarela seperti Tan Kah Kee yang menjadi ketua Tabung Bantuan China dan pengikutnya, pendatang Cina selepas Perang China-Jepun tahun 1937, ahli kongsi gelap, pegawai kerajaan, orang ramai yang pro-British, pemilik senjata api dan pengacau (Mohamad Isa 1992, 102). ${ }^{12}$ Chin Kee Onn pula menyatakan bahawa guru sekolah, khasnya dari sekolah Cina, pelajar dan sesiapa yang kelihatan seperti intelektual menjadi sasaran tentera Jepun (Chin 1976, 98). Tan Liok Ee sependapat dengan Chin di mana dalam mangsa "Sook Ching" adalah guru dan pelajar sekolah Cina kerana ada di antara mereka yang paling komited dalam politik mungkin telah menyertai pasukan penentang dalam hutan di bawah pimpinan Parti Komunis Malaya (PKM) atau kumpulan gerila yang ditubuhkan oleh KMT (Tan 1997, 87-88).

Sememangnya warga Chung Ling merupakan golongan guru dan pelajar dari sekolah Cina yang tersohor di Tanah Melayu. Pada masa yang sama, warga Chung Ling memenuhi kriteria tiga golongan pertama orang Cina yang menjadi mangsa: penyokong KMT dan komunis serta pengikut Tabung Bantuan China yang diketuai Tan Kah Kee. Tidak dinafikan latar belakang Chung Ling yang "revolusioner" dan sifat kepartian (KMT) yang menebal sehingga boleh dianggap sebagai sekolah KMT, malah sifat kepartian lebih ketara sejak dipimpin oleh David Chen yang merupakan penyokong setia KMT. Lebih-lebih lagi, gerakan anti-Jepun mereka sebelum perang begitu rancak dan dikenali ramai dengan penglibatan dalam pelbagai aktiviti sedemikian. Sebilangan warga sekolah juga kembali memberi sumbangan di China sama ada dengan KMT, misalnya David Chen, atau komunis untuk menentang Jepun. Justeru, Chung Ling tidak dapat mengelakkan diri daripada menjadi sasaran utama tentera Jepun semasa "Sook Ching" dijalankan di Pulau Pinang.

Secara amnya, sebelum “Sook Ching”, Chung Ling seperti sekolah-sekolah Cina yang lain telah mengalami penutupan dan kemusnahan. Zaman Pendudukan 
Jepun telah dilihat sebagai tempoh paling gelap dalam sejarah pendidikan Cina di Tanah Melayu yang menyaksikan guru dan pelajar sekolah dibunuh, sekolah ditutup dan bangunan sekolah dimusnahkan. Perkembangan pendidikan Cina di Tanah Melayu terbantut juga kerana penggunaan bahasa Cina sebagai bahasa pengantar sekolah diharamkan khasnya selepas Mac 1944 (1219 Huajiao Shenghui Gongweihui Shiliaozhan Zu 1993, 4; Tan 2014, 55).

Selepas Jepun menakluki Pulau Pinang, Chung Ling memasuki zaman gelap yang bermula dengan dua premis Chung Ling di Jalan Northam (Jalan Sultan Ahmad Shah) dan Kampung Baru telah ditutup. Premis di Kampung Baru kemudian dijadikan oleh tentera Jepun sebagai pusat latihan sebelum ditukar kepada pusat pentadbiran negeri. Lebih teruk lagi, aset dan peralatan sekolah sama ada telah musnah atau dicuri (Chen 2017, 22, 25; Xie 1947, 22). ${ }^{13}$ Ia merupakan satu "malapetaka" dalam perkembangan sejarah Chung Ling. Ahli-ahli Jemaah Pengurus Chung Ling dikatakan sama ada kembali ke China atau melarikan diri atau bersembunyi (Xie 1947, 22). Penutupan sekolah juga menyebabkan guruguru Chung Ling menganggur dan terpaksa mencari jalan keluar untuk menyara kehidupan keluarga. Ada di antara mereka seperti Guan Lianggong (管亮工) menjual minuman ais, Rong Weisheng (荣渭生) menjual telur dan Wang Kaijing (汪开竞) membuka gerai kopi (Wang Y. 1947, 25). Walau bagaimanapun, ada perkembangan selanjutnya yang lebih mengancam keselamatan mereka. Pihak Jepun sudah mula mengambil perhatian terhadap guru Chung Ling apabila ada perisik pergi ke rumah Rong Weisheng untuk menjalankan penyiasatan. Ada khabar angin menyatakan Chung Ling sebagai badan komunis. Keadaan diburukkan lagi apabila buku yang diambil keluar oleh seorang penjaja dari premis Chung Ling di Jalan Northam untuk kegunaan sendiri kebetulannya mempunyai isi kandungan anti-Jepun dan telah dikesan di tengah jalan oleh perisik (Wang 1947, 25). Ada kemungkinan segala buku, terutamanya buku Cina, dianggap ada unsur-unsur anti-Jepun. Maka, selepas pendudukan Jepun, Kempeitai sibuk mengumpul bukubuku itu untuk dibakar. Laporan Chan Yik King menyatakan buku yang dibakar di Berek Polis Jalan Penang mencecah tidak kurang daripada 200 ribu (File of Chan Yik King n.d.). Tidak dapat dinafikan selain buku anti-Jepun yang disimpan di Chung Ling, rekod atau dokumen berkaitan sekolah sekiranya jatuh ke tangan pihak Jepun boleh membawa padah kepada warga sekolah. Setiausaha Persatuan Alumni Chung Ling, Zeng Qianfu (曾谦福) bersama seorang lagi alumni, Chen Quanfu (陈泉福) telah mengambil langkah berjaga-jaga dengan membakar semua dokumen dan buku yang ada dalam premis persatuan di Jalan Penang sehari sebelum Jepun mendarat di Pulau Pinang (Chen 1997, 131-132). Namun, keadaan bertambah buruk dan azab telah menimpa warga Chung Ling pada bulan April 1942 dengan berlakunya penangkapan dan pengorbanan nyawa yang dahsyat dalam Operasi "Sook Ching". Mengikut kajian Paul H. Kratoska tentang Operasi "Sook Ching" di Pulau Pinang: 
A mass screening was carried out in the Georgetown area of Penang on 5 April 1942, and elsewhere on the island the next day. Masked informers identified people who fell into four suspect categories: those who had worked against Japan, communists, educated people and criminals. In Penang those selected, possibly as many as 5,000 men, were taken to the prison to await further interrogation. Some detainees were eventually released, some were executed and a substantial number died when cholera swept through the overcrowded cells (Kratoska 1998, 99).

Apabila diteliti, permulaan Operasi "Sook Ching" yang pertama ini mempunyai dua versi tarikh. Kratoska telah mengenepikan tarikh yang disebut oleh Lee Kit Yeng iaitu 6 April 1942, tetapi mengikuti tarikh yang disebutkan Baba Ahmed bin Ahmed iaitu 5 April (Kratoska 1998, 99). Dalam buku Ahmed Meah bin Baba Ahmed yang disusun berdasarkan buku harian bapa beliau iaitu Baba Ahmed bin Ahmad yang bertugas sebagai Pembantu Perubatan di Dispensari Pesakit Luar Kerajaan Lebuh Buckingham pada masa itu, operasi tersebut yang digelar Operasi Lingkaran Penjagaan (cordon) diberhentikan pada petang 7 April (Ahmed 1992, xi, xv-xvi, 47-48). ${ }^{14}$ Beberapa sumber lain, daripada Wang Yang (汪洋), Fang Nianzu (方念祖) dan Han Kok Foo (Han Juefu 韩觉夫) telah mengemukakan permulaan "Sook Ching" pada 6 April (Wang Y. 1947, 26; Fang 1984, 510; Han 1979, 127). Namun, dalam kajian Sejarah Chung Ling oleh Tan Eng Chaw (Chen Rongzhao 陈荣照) dan Wong Hong Teng (Wang Kangding 王慷鼎), apabila "Sook Ching" yang pertama disebut, ia berlangsung selama dua hari: 5-6 April (Chen 2017, 25; Wang 2017b, 290). Sebenarnya, dalam sejarah ringkas guru Chung Ling yang terkorban, ada di antara mereka yang diberkas oleh Kempeitai pada 5 April menandakan operasi telah bermula pada hari itu (Zhongzhong Jinian Xunnan Shisheng Weiyuanhui Bianjizu 1947, 9-12).

Dalam huraian Fang Nianzu, "Sook Ching" yang pertama dijalankan pada 6 April di tujuh kawasan berasingan dari pagi sampai pukul sembilan malam. Hubungan jalan raya terputus dan suratkhabar dilarang menyiarkan peristiwa itu. Setiap individu dipaksa meninggalkan rumah mereka untuk berkumpul di tempat yang ditetapkan. Beberapa peringkat pemeriksaan dijalankan, misalnya peringkat pertama iaitu menahan mereka yang bertatu. Hal ini menunjukkan tentera Jepun menumpukan perhatian kepada orang Cina dalam operasi itu kerana tatu di badan selalu didapati dalam kalangan komuniti ini. Peringkat seterusnya ialah berjalan melihat ke atas tingkap sebuah rumah untuk dicamkan oleh seorang penyiasat. Jumlah yang ditangkap dalam operasi pertama melebihi 2,000 orang. Operasi berterusan di luar bandar pada hari selanjutnya (7 April) dan diikuti pemeriksaan berselerak pada hari yang lain. Jumlah yang dilepaskan selepas itu tidak sampai $25 \%$ daripada yang diberkas kerana baki (sekitar $75 \%$ ) sama ada mati atau terus dipenjarakan (Fang 1984, 510-511). ${ }^{15}$ Dalam buku Ahmed Meah bin Baba Ahmed, rakyat di beberapa kawasan George Town pada 5 April telah diusir keluar 
dari rumah masing-masing untuk berhimpun di satu tempat. Mereka kemudian diarah berjalan melalui sebuah pondok kecil di mana seorang yang bertopeng akan mengesan anasir-anasir komunis atau penyokong-penyokongnya (Ahmed 1992, 47). Mengikut Yi Teng (依藤) (nama pena yang digunakan oleh guru Chung Ling iaitu Wang Kaijing), hubungan jalan raya pulih pada 9 April (Yi 1957, 64). Menurut Lim Beng Kooi, "Sook Ching" di Pulau Pinang berskala kecil berbanding dengan Perak atau Johor atas kekurangan aktiviti komunis secara relatifnya. Sungguhpun begitu, Kempeitai dalam operasi ini tidak membezakan antara Orang Cina Selat (Straits Chinese) dengan Orang Cina Seberang Laut. Hal ini telah menimbulkan ketidakpuasan Orang Cina Selat kerana mereka tidak terlibat dalam aktiviti antiJepun (Lim 1973/74, 12, 19-20). Namun, terdapat satu persamaan dalam kajian Lim Beng Kooi dan Paul H. Kratoska iaitu Operasi "Sook Ching" di Pulau Pinang menumpukan perhatian terhadap guru dan pelajar Chung Ling (Lim 1973/74, 11; Kratoska 1998, 99).

Sekiranya diteliti kes-kes penangkapan warga Chung Ling dalam Operasi "Sook Ching" tersebut, ia bermula pada 5 April dengan penangkapan guru secara berasingan di rumah kediaman mereka: Lin Zhenkai (林振凯) dan Rao Baiying (饶 百迎), kecuali Zhu Xuanyi (朱宣义) diberkas di Jalan Penang. Penangkapan pada hari berikutnya (6 April) diteruskan dengan penangkapan guru di rumah kediaman: Li Ciyong (李词佣), Ke Zitong (柯梓桐), Jian Dehui (简德辉), Huang Bafu (黄峇 福), dan seorang alumni Cen Wenxiu (岑文秀). Namun, ada guru yang ditangkap dalam pemeriksaan beramai-ramai pada hari tersebut iaitu Guan Lianggong, Cha Qitang (查企唐), dan Wang Shiyi, manakala pelajar atau alumni Chung Ling yang ditangkap melalui cara ini ialah Chen Shijing (陈士景), Huang Yaohui (黄耀辉), Xie Xuehai (谢学海), Chen Kejun (陈克俊), Ouyang Hengfang (欧阳衡芳), Xu Fuyan (许福炎), dan Lin Guoliang (林国良). Xie Songshan (谢松山) berdasarkan makluman daripada rakannya telah menjelaskan bahawa kebanyakan mangsa yang ditangkap dalam pemeriksaan beramai-ramai terdiri daripada guru dan pelajar Chung Ling. Pada hakikatnya, dalam senarai pelajar atau alumni Chung Ling yang terkorban, ada di antara mereka telah ditangkap lebih awal daripada Operasi "Sook Ching”, misalnya Xie Guoren (谢国仁) ditangkap pada 21 Februari 1942. Dua lagi kes dalam kategori ini sebenarnya telah mati semasa George Town diserang oleh pesawat pengebom tentera Jepun iaitu Chen Liuqian (陈六谦) dan Yang Jinwa (杨金华) pada 11-12 Disember 1941, manakala satu kes mati atas tembakan polis pada 13 Disember 1941 sebelum tentera Jepun mendarat. Jika diteliti senarai tersebut yang mempunyai 46 pelajar atau alumni, seramai 13 orang ditangkap dalam bulan April 1942, termasuk mereka yang ditangkap pada 6 April. Ada di antara mereka ditangkap lebih lewat pada tahun 1945. Sebahagian besar iaitu 29 kes penangkapan atau pengorbanan berlaku di Pulau Pinang, manakala selainnya berlaku di Singapura, Kampar, Arau, Kuala Kangsar, Johor, Baling, dan Betong (Zhongzhong Jinian Xunnan Shisheng Weiyuanhui Bianjizu 1947, 9-12, 
15-19; Wang Y. 1947, 26; Xie 1984, 518). ${ }^{16}$ Maka, penangkapan warga Chung Ling oleh tentera Jepun bertumpu pada bulan April 1942 terutamanya 6 April.

Yi Teng telah menjelaskan terdapat dua cara penangkapan oleh tentera Jepun. Cara pertama ialah penangkapan pada tengah malam dengan menangkap mangsa di rumah kediaman mengikut senarai yang diberi oleh tali barut. Cara kedua ialah penangkapan beramai-ramai dengan memberi arahan untuk mengumpulkan orang ramai ke satu tempat, seterusnya mangsa dikenal pasti oleh orang bertopeng (Yi 1957, 63). Apabila diperhatikan huraian tentang penangkapan dalam pemeriksaan beramai-ramai, akan wujud orang bertopeng yang membantu pihak Jepun mengenal pasti mereka yang anti-Jepun atau anasir-anasir komunis. Lim Kean Siew menyifatkan "orang Jepun telah membawa ketakutan kepada negara dan keganasan melalui lelaki bertopeng dalam "perhimpunan beramai-ramai" (the Japanese had brought fear to the country and terror through the hooded men of the "roundups") (Lim 1999, 146). Chin Kee Onn pula menghuraikan orang ramai dipaksa berjalan seorang demi seorang di hadapan sebarisan "pengganas bertopeng" (hooded terrors) yang merupakan bekas komunis yang berpaling tadah menjadi pengintip dan pemberi maklumat kerajaan (Jepun). Mereka yang bertopeng mungkin lelaki atau wanita, budak lelaki atau gadis. Anggukan kepala terhadap mana-mana individu oleh salah seorang yang bertopeng menandakan mangsa tersebut dikenal pasti dan akan ditahan lalu dibawa ke bilik tahanan (Chin 1976, 99).

Dalam senarai warga Chung Ling yang terkorban, nama dua orang bertopeng yang bertanggungjawab atas pengorbanan itu telah disebut iaitu Huang Kaicong (黄开聪) dan Xu Yuye (许玉叶). Adalah didapati mereka yang terkorban: Guan Lianggong dicam oleh Huang, manakala Jian Dehui dan Cha Qitang dicam oleh Xu dalam Operasi "Sook Ching" (Zhongzhong Jinian Xunnan Shisheng Weiyuanhui Bianjizu 1947, 9, 11-12). ${ }^{17}$ Antara dua orang bertopeng, Xu merupakan orang bertopeng yang paling ditakuti dan dibenci oleh warga Chung Ling. $\mathrm{Xu}$, seorang wanita bertopeng yang berbangsa Taiwan merupakan penterjemah di Jabatan Kempeitai. Xu merupakan isteri kepada Wu Tingqian (巫廷谦), seorang doktor yang juga berbangsa Taiwan dan berkhidmat di hospital kerajaan Pulau Pinang semasa Zaman Pendudukan Jepun. Adalah dikatakan semasa tercetusnya Perang Pasifik, Xu pernah dipenjarakan oleh kerajaan British selama dua minggu dan ingin menggunakan kesempatan itu untuk membalas dendam (Han 1979, 127; Yi 1957, 63-64). Orang berbangsa Taiwan kerap diambil oleh orang Jepun untuk berkhidmat dengan mereka, misalnya sebagai penterjemah dalam banyak jabatan pentadbiran Jepun (Wong 1973/74, 5).

$\mathrm{Xu}$ pernah mendesak Jabatan Kempeitai sekiranya mereka ingin menangkap komunis, penangkapan guru Chung Ling sudah memadai. Dalam pemeriksaan beramai-ramai di Air Itam, Xu dikatakan telah mengancam warga Chung Ling akan dibunuh sekiranya tidak tampil ke hadapan. Mereka, termasuk 
dua guru iaitu Wang Shiyi dan Cha Qitang, telah mengaku. Setelah disahkan oleh $\mathrm{Xu}$, mata-mata gelap akan menulis "Zhong" (锤, singkatan nama untuk Chung Ling) di belakang badan sebelum dihantar ke Penjara Pulau Pinang (Wang Y. 1947, 25-26).

\section{KESAN “SOOK CHING” TERHADAP CHUNG LING}

Selepas berita tentang warga Chung Ling ditangkap, ramai pemilik kedai berada dalam ketakutan sehingga enggan mengambil kumpulan tersebut sebagai staf dan dipecat. Warga Chung Ling yang bernasib baik terselamat daripada operasi sama ada berhati-hati dengan pergerakan atau bersembunyi. Namun, beberapa guru Chung Ling seperti Xie Youqing (谢幼青), Guan Zhenmin (管震民) dan Wang Kaiming (汪开明) tidak berputuas asa dan berulang kali pergi ke rumah pemimpin KMT iaitu Goh Say Eng (Wu Shirong 吴世荣) untuk berbincang demi mencari jalan menyelamatkan rakan sejawat dan pelajar. Pelan tersebut terpaksa ditangguhkan kerana tanggapan negatif pihak Jepun terhadap Chung Ling dan sukar dijalankan sekadar atas usaha mereka sahaja (Wang Y. 1947, 26).

Ramai mangsa, di antaranya warga Chung Ling yang ditangkap melalui Operasi "Sook Ching" telah dihantar ke Penjara Pulau Pinang. Manicasothy Saravanamuttu, bekas editor Straits Echo Pulau Pinang dan bekas Pengerusi Jawatankuasa Perkhidmatan Pulau Pinang (sebelum pendaratan Jepun) telah merakamkan pengalamannya dalam penjara itu semasa awal pendudukan Jepun. Saravanamuttu telah mendapati ratusan orang telah dibawa ke Penjara Pulau Pinang sebaik sahaja Kempeitai mula beroperasi pada bulan Mac/April 1942. Adalah didapati beribu-ribu orang telah dipenjara dan diseksa. Ramai yang telah mati termasuk mereka yang tidak bersalah. Saravanamuttu telah mengesan kebanyakan yang dibawa masuk pada awalnya ialah guru dan pelajar Chung Ling kerana pihak Jepun mengesyaki sekolah itu sebagai "sarang Komunis" (Communist cell). Mengikut Saravanamuttu lagi, selain komuniti Serani, staf dan pelajar Chung Ling merupakan satu lagi kumpulan yang menjadi sasaran khas Kempeitai (Saravanamuttu 2010, 132-133, 138-139). Bekas pelajar Chung Ling dan juga bekas pemimpin Singapura, Lee Khoon Choy (Li Jiongcai李昫才) telah memberi hujah bahawa seramai 200 orang pelajar Chung Ling yang dipenjarakan di penjara tersebut telah diarahkan berbaris dan ditembak sampai mati (Li 1989, 76). Hujah ini sukar dipersetujui kerana tiada bukti yang menunjukkan begitu ramai pelajar yang terkorban. Sungguhpun demikian, tidak dapat dinafikan ramai warga Chung Ling dipenjarakan, diseksa dan mati dalam penjara.

Sememangnya mereka yang dipenjarakan akan disoal siasat secara giliran. Wang Shiyi masih mengingati Xu Yuye yang menjadi penterjemah semasa sesi soal siasat dijalankan dan Wang bernasib baik kerana tidak diseksa. Kempeitai ingin 
mengenal pasti anasir-anasir komunis dalam sekolah melalui soal siasat (Wang Y. 1947, 27-28). Catatan Manicasothy Saravanamuttu sebelum itu bahawa pihak Jepun mengesyaki Chung Ling sebagai "sarang komunis", bukanlah kenyataan yang tidak berasas. Selain warga Chung Ling terutamanya pelajar yang kembali ke China menyertai komunis atau PKC, satu lagi kumpulan wujud menjelang dan semasa pendudukan Jepun menyertai PKM khasnya Malayan People's AntiJapanese Army (MPAJA) atau lebih dikenali sebagai Bintang Tiga (Wang 2017b, 273-287). Guru-guru Chung Ling yang lain seperti Cha Qitang, Ke Zitong, Lin Zhenkai, Zhu Xuanyi, Rao Baiying dan Jian Dehui telah diseksa dengan dahsyat semasa soal siasat dijalankan. Guan Lianggong yang merupakan jurulatih kungfu diseksa dengan menuang air melalui mulut (Li 1989, 75). Pada masa yang sama, keadaan dalam Penjara Pulau Pinang sangat teruk dan penuh sesak dengan banduan. Sebagai contoh, baldi air minuman ada kalanya dicemari baldi najis sehingga penyakit cirit-birit berjangkit. Ramai yang mati kerana penyakit berjangkit tersebut. Ada guru Chung Ling yang dilepaskan telah meninggal dunia dalam masa singkat. Cha Qitang yang dilepaskan telah mati sebelum sampai ke rumah pada 8 Julai 1942 manakala Rao Baiying yang badannya semakin lemah akibat seksaan telah mati pada 7 Julai 1943 selepas dilepaskan (Zhongzhong Jinian Xunnan Shisheng Weiyuanhui Bianjizu 1947, 12; Wang Y. 1947, 28-29; Wang S. 1947, 30). ${ }^{18}$ Guru-guru lain yang tidak sempat dilepaskan dari penjara telah terkorban. Guan Lianggong mogok lapar dan mati pada 23 Jun 1942; Li Ciyong diseksa hingga mati pada 5 Jun; Ke Zitong ingin membunuh diri selepas seksaan berterusan tetapi tidak berjaya sehingga menjadi cacat dan meninggal dunia pada 12 Julai; Zhu Xuanyi dan Lin Zhenkai mengalami kesakitan berterusan selepas seksaan dan masing-masing meninggal pada 8 Julai dan 15 Ogos; Jian Dehui diseksa dengan teruk dan tarikh kematiannya tidak dapat dipastikan manakala ada berita mengatakan Jian membunuh diri (Zhongzhong Jinian Xunnan Shisheng Weiyuanhui Bianjizu 1947, 9-11).

Setahun selepas berlakunya "Sook Ching" pertama, satu perkembangan yang menunjukkan Chung Ling masih menjadi sasaran ialah apabila seorang guru Chung Ling, Huang Shuangren (黄霜仁) dipenjarakan pada tahun 1943. Kempeitai menangkap Huang atas tuduhan mencetak mata wang tentera tetapi selepas soal siasat dan mengetahui statusnya sebagai guru Chung Ling, tuduhan tersebut diketepikan dan tumpuan beralih kepada soal anti-Jepun dan komunis (Huang 1947, 33-34). Jelasnya pihak Jepun sangat takut kepada kumpulan komunis sehinggakan Chin Kee Onn menyifatkan mereka sebagai "fobia komunis" (communist phobia) (Chin 1976, 100). Ada catatan memaparkan warga Chung Ling menjadi sasaran di kawasan selain Pulau Pinang. Misalnya di sekitar kawasan Kulim dan Baling, warga Chung Ling merupakan salah satu sasaran Kempeitai tempatan. Hal ini menyebabkan beberapa pelajar Chung Ling seperti Yi Yancheng 
(易延成) dan Huang Wenrui (黄文瑞) yang berada di Baling telah diberkas dan mati di dalam penjara (Zhang 1947, 36).

Selanjutnya, Operasi "Sook Ching" yang kedua telah berlaku pada 15 September 1942. Ia dijalankan mengikut senarai nama di beberapa kawasan secara berasingan dengan bantuan orang bertopeng. Mereka yang ditahan akan dipangkah "X" atau "gong" (共 atau komunis) di belakang badan sebelum dibawa ke tempat lain. Operasi "Sook Ching" pada kali ini telah menahan antara 2,000 hingga 3,000 orang, kebanyakannya orang Cina yang menceburi bidang kebudayaan. Beberapa Operasi "Sook Ching" berskala kecil yang memberkas ramai orang juga pernah dijalankan iaitu selepas peristiwa pengeboman perarakan perayaan Kigen Setsu (Empire Day) pada 11 Februari 1942. Satu lagi operasi berlaku selepas "Kes Bendera" apabila ada orang mengibarkan bendera dan melekatkan risalah propaganda anti-fasis di Air Itam pada 18 September 1942 untuk memperingati Peristiwa 18 September, hari berlakunya pencerobohan tentera Jepun ke Timur Laut China (Fang 1984, 511-512). Operasi "Sook Ching" terhadap orang Cina di Tanah Melayu telah diberhentikan menjelang bulan Mac 1943 disebabkan Jepun memerlukan sokongan orang Cina untuk memulihkan kegiatan ekonomi (Mohamad Isa 1992, 102). Operasi ini dikatakan telah memaksa ratusan orang Cina sama ada muda atau dewasa melarikan diri ke dalam hutan untuk menyertai gerakan penentangan yang dipimpin oleh komunis iaitu MPAJA (Cheah 2012, 24). Sememangnya keganasan yang dialami dalam kalangan warga Chung Ling tidak menakutkan mereka untuk terus menentang Jepun. Ramai di antara mereka seperti pelajar selain menyertai MPAJA, juga menyertai kumpulan penentang yang lain seperti Pasukan 136 (Wang 2017b, 271-289).

Sehingga tamatnya Zaman Pendudukan Jepun, rekod yang ditemui telah menunjukkan seramai 54 warga Chung Ling (8 guru dan 46 pelajar/alumni) terkorban semasa Zaman Pendudukan Jepun (Zhongzhong Jinian Xunnan Shisheng Weiyuanhui Bianjizu 1947, 6). Guru-guru Chung Ling yang masih hidup selepas keluar dari penjara hanya tinggal Wang Shiyi, Huang Bafu, Mei Yingrong (梅英荣), Huang Shuangren dan Lin Jiayang (林嘉扬). Namun, Huang Bafu menjadi buta kerana kecederaan satu mata (Xie 1947, 22; Chen 2017, 26). Tidak hairanlah Wu Tiren (吴体仁) telah membuat kesimpulan bahawa semasa Zaman Pendudukan Jepun, pengorbanan guru dan pelajar Chung Ling telah mencatat rekod paling tinggi dalam sektor budaya dan pendidikan Pulau Pinang (Wu 1984, 525). 


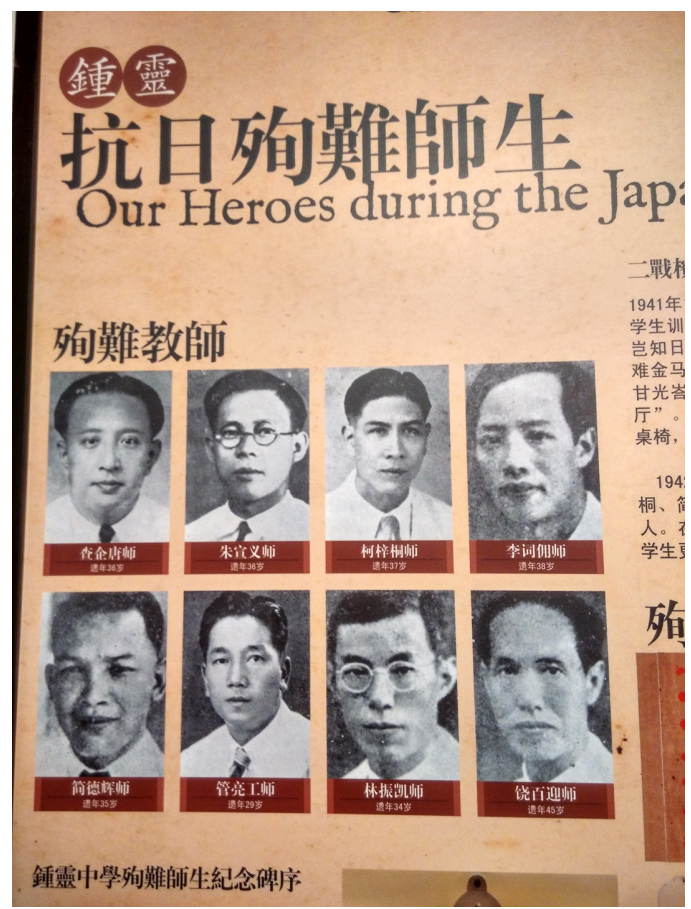

Rajah 3: Foto lapan orang guru Chung Ling yang terkorban semasa Operasi "Sook Ching”. Baris pertama (dari kiri ke kanan): Cha Qitang (查企唐), Zhu Xuanyi (朱宣义), Ke Zitong (柯梓桐), Li Ciyong (李词佣); Baris kedua (dari kiri ke kanan): Jian Dehui (简德辉), Guan Lianggong (管亮工), Lin Zhenkai (林振凯), Rao Baiying (饶百迎),

Sumber: Papan pameran Arkib Chung Ling (foto diambil oleh penulis pada tahun 2017).

\section{PENGADILAN DAN PERINGATAN "SOOK CHING" CHUNG LING}

Selepas Jepun menyerah kalah, Mahkamah Penyiasatan Penjenayah Perang Pulau Pinang telah memulakan perbicaraan pada 30 Ogos 1946. Ia dipimpin oleh Leftenan Kolonel Smith. Perbicaraan diadili berdasarkan senarai nama dan rekod kesalahan penjenayah perang yang disusun oleh seorang ketua perisik KMT, Liu Geqing (刘戈清), dan Jawatankuasa Aduan Masyarakat Cina Pulau Pinang serta penjelasan oleh saksi atau mangsa yang pernah mengalami tindakan kekejaman pihak Jepun dan yang masih hidup. Keputusan perbicaraan telah menunjukkan 21 orang dijatuhi hukuman mati, 11 orang dihukum penjara dan 3 orang dibebaskan (Chen 1997, 299-300).

Merujuk kepada catatan Han Kok Foo, Rombongan Penyiasatan Penjenayah Perang di Pulau Pinang sebenarnya telah mengemukakan senarai nama 61 orang yang disyaki terlibat dalam jenayah perang semasa Zaman 
Pendudukan Jepun. Selepas itu, hanya 35 orang daripadanya telah didakwa. Mereka telah didakwa atas kesalahan kolektif antara bulan Mac 1942 hingga bulan September 1945 iaitu menjalankan pelbagai jenis penyeksaan sehingga menjadikan lebih daripada 1,000 penduduk tempatan terkorban. Daripada 35 orang itu, ketua detektif Jepun iaitu Okawa telah ditambah satu lagi kesalahan iaitu menganiayai orang Serani. Perbicaraan di Pulau Pinang telah tamat pada 30 September 1946 (Han 1979, 54-55, 65; Chen 1997, 300-301).

Jika ditinjau lebih lanjut, di antara penjenayah-penjenayah perang Pulau Pinang, salah seorang ketua Kempeitai Pulau Pinang iaitu Higashigawa Yoshinobu yang memegang jawatan dari Mac 1942 hingga 20 Mac 1943 merupakan perancang utama "Sook Ching" Pulau Pinang. Higashigawa telah dijatuhi hukuman mati. Xu Yuye sebagai wanita bertopeng yang menyebabkan ramai warga Chung Ling terkorban telah dibebaskan selepas perang dan kembali ke Taiwan. Sungguhpun demikian, Xu kemudian telah dibicara dan dipenjarakan selama 10 tahun oleh Mahkamah Tinggi Taiwan. Hal ini berlaku selepas rayuan Pengetua Chung Ling, David Chen sampai kepada Kementerian Pertahanan Kerajaan Nasionalis China (Chen 1997, 300-301).

Pengorbanan warga Chung Ling semasa Zaman Pendudukan Jepun terutamanya dalam Operasi "Sook Ching" merupakan satu peristiwa ngeri yang tidak mudah dilupakan. Sebagai memperingati dan membantu keluarga mereka yang terkorban, tidak lama selepas sekolah dibuka selepas tamatnya perang, Chung Ling mula membuat pendaftaran warga sekolah yang terkorban pada 15 Oktober 1945 disusuli dengan menubuhkan Jawatankuasa Memperingati Warga Chung Ling Terkorban pada 19 Disember 1945. Jawatankuasa tersebut akan mengadakan majlis belasungkawa, menerbitkan buku peringatan, membina tugu peringatan dan mengutip dana untuk keluarga warga Chung Ling yang terkorban. Majlis belasungkawa telah diadakan pada 28 Februari 1946 sempena perletakan batu asas tugu peringatan di Chung Ling. Buku Peringatan iaitu "Rekod Pengorbanan Guru dan Pelajar Sekolah Menengah Chung Ling Pulau Pinang" (Bincheng Zhongling Zhongxue xunnan shisheng rongailu 槟城锤灵中学殉难师生荣哀录) diterbitkan pada 18 Januari 1947 diikuti upacara perasmian tugu peringatan pada 8 Disember (Zhongzhong Jinian Xunnan Shisheng Weiyuanhui Bianjizu 1947, 3, 6, 20; Ye 2009, 74). Peringatan untuk warga Chung Ling yang terkorban tidak terhenti setakat ini sahaja tetapi pernah diadakan pada ulang tahun tertentu. Sebagai contoh, sempena ulang tahun ke-50 tamatnya Perang Dunia Kedua, ketiga-tiga Sekolah Chung Ling iaitu Sekolah Menengah Jenis Kebangsaan (SMJK) Chung Ling Pulau Pinang, Sekolah Menengah Persendirian Chung Ling dan SMJK Chung Ling Butterworth telah mengadakan majlis belasungkawa pada 15 Ogos 1995 untuk warga Chung Ling yang terkorban semasa Zaman Pendudukan Jepun (Chen 2017, 89). 
Tan Chee Seng

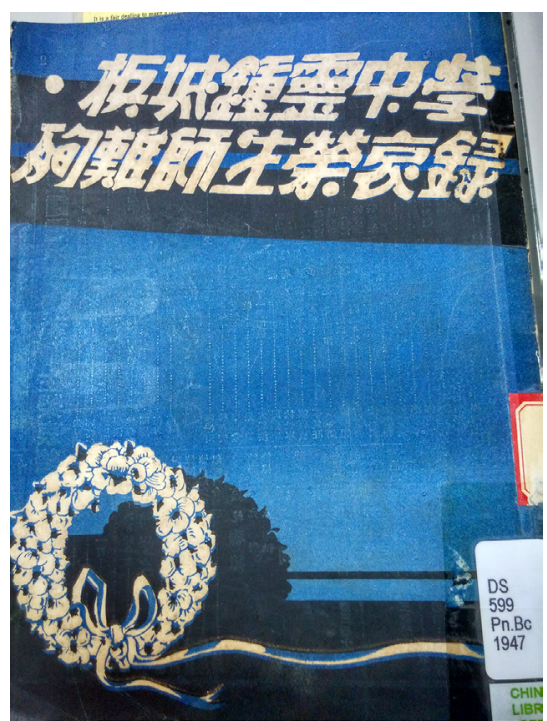

Rajah 4: Muka depan Bincheng Zhongling Zhongxue Xunnan Shisheng Rongailu 槟城锤灵中学殉难师生荣哀录 (Rekod Pengorbanan Guru dan Pelajar

Sekolah Menengah Chung Ling Pulau Pinang).

Sumber: Zhongzhong Jinian Xunnan Shisheng Weiyuanhui Bianjizu 锤中纪念殉难师生委员 会编辑组 (1947) (Koleksi simpanan National University of Singapore Chinese Library)

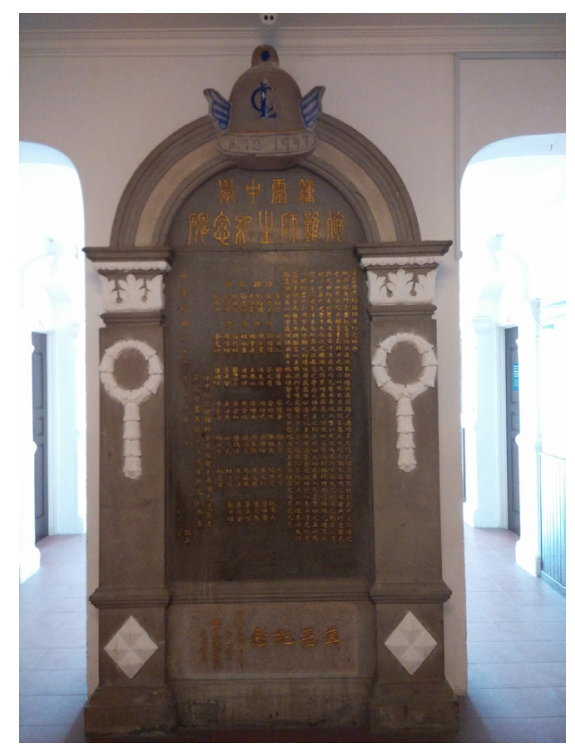

Rajah 5: Foto Tugu Peringatan Chung Ling.

Sumber: Foto diambil oleh penulis di hadapan Dewan Perhimpunan SMJK Chung Ling Pulau Pinang pada tahun 2017. 


\section{KESIMPULAN}

Kesimpulannya, latar belakang Chung Ling menjadikannya sebagai sebuah sekolah bersifat revolusioner dan perkembangan seterusnya yang mempelopori sekolah-sekolah Cina di Tanah Melayu telah menjadikan Chung Ling sebagai sebuah sekolah yang unik di rantau ini. Dengan pimpinan Pengetua David Chen, Chung Ling bukan sahaja melangkah ke depan menjadi sekolah tersohor di rantau ini, malah sifat kepartian KMT semakin ketara. Pada masa yang sama, keadaan yang berlaku di China telah mempengaruhi sekolah tersebut, terutamanya sejak tahun 1937 dengan tercetusnya Perang China-Jepun Kedua. Gerakan anti-Jepun di Chung Ling menjadi semakin rancak dan melibatkan warga Chung Ling dalam pelbagai aktiviti yang dapat membantu tanah air mereka menentang Jepun. Warga Chung Ling bukan sahaja kembali ke China untuk berkhidmat dengan KMT dan Kerajaan Nasionalis, tetapi juga komunis atau PKC. Sememangnya tindakan ini telah menjadikan Chung Ling sebagai sasaran utama tentera Jepun semasa Zaman Pendudukan Jepun. Menerusi Operasi "Sook Ching" khususnya kali pertama antara 5-6 April 1942, warga Chung Ling telah mengalami satu "malapetaka" yang tidak diduga, malahan tidak pernah dialami sebelum itu. Ramai warga Chung Ling ditangkap, diseksa dan telah terkorban. Namun, ia tidak menakutkan warga sekolah dan ada di antara mereka tetap menyertai gerakan anti-Jepun iaitu MPAJA atau kumpulan penentang yang lain. Tugu peringatan di SMJK Chung Ling menunjukkan pengalaman pahit yang dialami warga Chung Ling. Tugu ini berfungsi sebagai peringatan dan pengajaran kepada generasi seterusnya untuk mencintai keamanan. Setakat ini tidak ada sumber dan kajian tentang "Sook Ching" yang diterbitkan di China atau Taiwan. Malah, sumber dan kajian sedemikian yang dapat dikesan atau disimpan di dua tempat tersebut pada hakikatnya diterbitkan di Malaysia dan Singapura. ${ }^{19}$ Signifikan artikel ini dipaparkan dengan membuktikan latar belakang dan keaktifan Chung Ling dalam aktiviti anti-Jepun menjadikan sekolah tersebut sebagai sasaran utama tentera Jepun sehingga melalui satu pengalaman paling ngeri dalam kalangan institusi pendidikan tempatan. Pada masa yang sama, hasil kajian telah membuktikan kes Chung Ling merupakan kes paling ketara dalam Operasi "Sook Ching" bukan sahaja di Pulau Pinang, bahkan di seluruh Tanah Melayu. Maka, artikel ini telah memberi suatu interpretasi baru dalam kajian "Sook Ching" yang memaparkan sebuah sekolah juga menerima kesan begitu ketara dalam operasi tersebut berdasarkan sumber-sumber bahasa Cina berkaitan Chung Ling yang tidak ditemui dalam mana-mana sumber lain. 


\section{PENGHARGAAN}

Penulis merakamkan penghargaan kepada Prof. Dr. Ooi Keat Gin yang memberikan cadangan dalam mengemaskini artikel ini. Penghargaan juga dituju kepada pihak Jemaah Pengurus Sekolah Menengah Chung Ling Negeri Pulau Pinang, terutamanya Encik Foo Wan-P'ng (Setiausaha) dan Encik Tham Kong Chee (Setiausaha Eksekutif) atas segala bantuan yang diberikan seperti kebenaran untuk menjalankan kajian dan mengambil foto di premis sekolah serta foto (Rajah 1-5) dimasukkan ke dalam artikel. Penulis juga berterima kasih atas bantuan yang dihulurkan semasa menjalankan penyelidikan di National University of Singapore Chinese Library khususnya Puan Amy Lin Yung Mei (Ketua Pustakawan) dan Puan Chong Loy Yin (Pustakawan).

\section{NOTA}

1. Chin Kee Onn menggunakan istilah mopping-up operations manakala Cheah Boon Kheng pula ialah Operation Clean-up. Mohamad Isa Othman menterjemahkan sebagai operasi pembersihan. Namun demikian, sama ada Chin atau Cheah ataupun satu lagi ulasan oleh Paul H. Kratoska sama-sama mentakrifkan sebagai purification by elimination. Lihat (Chin 1976, 99; Cheah 2012, 21; Mohamad Isa 1992, 102; Kratoska 1998, 95).

2. Nama "Sekolah Menengah Chung Ling Pulau Pinang" akan disingkatkan sebagai "Chung Ling" dalam perbincangan seterusnya, kecuali huraian asal-usul sekolah yang bermula sebagai peringkat sekolah rendah yang akan menggunakan istilah "Sekolah Chung Ling".

3. Sekolah menengah Cina yang pertama di Tanah Melayu dan juga Nanyang ialah Sekolah Menengah Huaqiao (Institusi Hwa Chong hari ini) di Singapura yang ditubuhkan pada tahun 1919. Pulau Pinang mengikut jejak langkah dengan penubuhan Sekolah Menengah Huaqiao Pulau Pinang pada tahun yang sama, namun ditutup dua tahun kemudian (1921) atas kekangan kewangan. Nama asal Sekolah Menengah Huaqiao Pulau Pinang ialah Sekolah Menengah Pulau Pinang (Bincheng Zhongxue 槟城中学), rujuk (Ye 1993, 68).

4. Buktinya ialah selain sekolah tersebut menerima elaun tertinggi antara sekolahsekolah Cina Tanah Melayu iaitu sebanyak \$11,340 pada tahun 1938, jumlah pelajarnya telah melonjak daripada 182 orang pada tahun 1926 kepada 1,055 orang pada tahun 1939 dengan 28 kelas. Lihat (Zheng 1999, 246, 265, 306).

5. Sebagai contoh, Chen telah menubuhkan Persatuan Bantuan Pelajar Sekolah Cina untuk melaksanakan Derma Harian (Wang Y. 1947, 23). Bantuan kewangan juga dihulurkan ke China dalam beberapa peristiwa penting. Peristiwa-peristiwa penting tersebut misalnya pencerobohan Jepun ke Shanghai (1932), mangsa di Timur Laut China (1933), mangsa banjir (1935), dan pembelian kapal terbang pejuang sempena kelahiran Chiang Kai-shek (1936). Rujuk (Ye 2009, 52-53). 
6. Adalah dianggarkan wang derma oleh guru dan pelajar Chung Ling sama ada untuk mangsa atau misi ketenteraan di negara China antara tahun 1937-1940 berjumlah \$40,661 Dolar Selat menjadikan Chung Ling mengatasi sekolah-sekolah Cina yang lain dalam usaha tersebut.

7. Aktiviti-aktiviti tersebut adalah seperti pertunjukan drama amal, pertandingan bola amal, jualan amal, jualan tulisan kaligrafi dan lukisan amal, jualan bunga dan bendera, pengumpulan pakaian sejuk, syarahan awam, propaganda, nyayian, terbitan artikel anti-Jepun dalam suratkhabar, majalah dan sebagainya.

8. Buktinya ialah nazir sekolah, Chan Yik King telah ditugaskan pada 27 Julai 1938 untuk memberi amaran kepada sekolah-sekolah Cina di Pulau Pinang dalam gerakan anti-Jepun di mana keengkaran mematuhinya akan dikenakan hukuman iaitu elaun sekolah dihentikan sehingga membawa kepada penutupan sekolah. Rujuk (Chen 2017, 24).

9. Dua guru iaitu Ye Suian (叶遂安) (tentera udara) dan Xu Qipan (许启泮) (tentera darat) dan seorang pelajar Zhang Shuilai (张水来) (tentera darat) masing-masing telah terkorban pada tahun 1940, 1941 dan 1945 semasa berperang dengan tentera Jepun. Guru-guru Chung Ling lain yang kembali ke China antara tahun 1937-1941 ialah Qian Jingcheng (钱景澄) (ke sekolah perubatan), Mao Gaoshan (茅睪 山) dan Wang Jianlong (王剑龙). Sebenarnya, ada sejumlah pelajar Chung Ling yang kembali ke China untuk memerangi Jepun. Mereka yang menyertai Kerajaan Nasionalis atau KMT terdiri daripada Chen Zaian (陈再安), Chen Deming (陈德 明), Chen Guocai (陈国才), Wen Zhenxiang (温振祥), Li Qiongfu (李琼福), Wu Yunbin (吴运涁), Hu Dexiu (胡德秀), Chen Yangshan (陈仰山), Bu Yaliang (布 亚良), Chen Shiyong (陈式勇), Ye Ji'an (叶继安), Wang Jiruo (王济弱) dan Rong Shengsong (容圣颂). Sebaliknya, ada satu lagi kumpulan pelajar telah menyertai komunis atau PKC yang berpusat di Yan'an (延安). Antaranya ialah Chen Qingshan (陈青山), Jiang Tian (江田), Xie Baiqiu (谢白秋), Guo Ling (郭凌), Shen Guang (沈光) (wartawan), Chen Ming (陈明), Chen Changhou (陈长侯), Chen Youru (陈 有儒) dan Li Lian (李廉). Rujuk (Wang 2017b, 248-254, 256-271; Zhongzhong Jinian Xunnan Shisheng Weiyuanhui Bianjizu 1947, 76-77).

10. Tidak ada nama dan butir-butir 14 pelajar tersebut. Chen di China pada mulanya menjawat Ketua Pengarah Sekolah Perubatan Zhongzheng (Zhongzheng Yixueyuan 中正医学院) sebelum ditawarkan jawatan Pengetua Sekolah Kerajaan Tentera Udara Belia (Guoli Kongjun Younian Xuexiao 国立空军幼年学校).

11. Azharudin Mohamed Dali juga sepandangan dengan Cheah iaitu antara ketiga-tiga masyarakat Melayu, Cina dan India, orang Cina dilihat menerima tekanan yang paling besar, termasuklah insiden pembunuhan beramai-ramai orang Cina iaitu "Sook Ching”. Lihat (Azharudin 2014, 275). P. Lim Pui Huen juga menyatakan Operasi "Sook Ching” menjadikan orang Cina sebagai sasaran. Lihat (Lim 1995, 138).

12. Brenda S.A. Yeoh dan Kamalini Ramdas mendapati 50,000 orang Cina telah dibunuh secara beramai-ramai dalam "Sook Ching" atas tanggapan sebagai "unsurunsur anti-Jepun" (anti-Japanese elements). Lihat (Yeoh and Kamalini 2000, 176).

13. Aset dan peralatan sekolah yanag musnah atau dicuri seperti buku, peralatan sains, ubat, spesimen, model, carta dinding, perkakas pejabat, dokumen dan sebagainya. 
14. Untuk melihat biodata Ahmed Meah bin Baba Ahmed dan bapa beliau iaitu Baba Ahmed bin Ahmad, rujuk (Ahmed 1992, xi-xvii, muka belakang).

15. Sebahagian daripada mereka yang dipenjarakan telah dilepaskan pada 19 dan 29 April.

16. Dalam senarai pelajar Chung Ling yang terkorban, sebenarnya jika diteliti catatan tambahan, ada sebahagian daripada mereka merupakan alumni.

17. Huang Kaicong merupakan alumni Chung Ling dan salah seorang pelajar yang giat dalam gerakan anti-Jepun. Selepas berpaling tadah, Huang dianggap sebagai pengkhianat oleh warga Chung Ling. Lihat (Chen 1997, 87).

18. Yi Teng telah memberi huraian tentang keadaan di Penjara Pulau Pinang dan caracara seksaan yang digunanakan. Rujuk (Yi 1957, 121-125). Fang Nianzu juga menjelaskan cara-cara seksaan tersebut dengan terperinci. Rujuk (Fang 1984, 511).

19. Semakan telah dilakukan terhadap sistem perpustakaan tempatan, misalnya Perpustakaan Kebangsaan China (National Library of China) di China: http://www. nlc.cn; dan Perpustakaan Kebangsaan Pusat (National Central Library) di Taiwan: http://www.ncl.edu.tw.

\section{RUJUKAN}

1219 Huajiao Shenghui Gongweihui Shiliaozhan $\mathrm{Zu}$ 1219华教盛会工委会史料展组. 1993. Huaguang yongyao: 1219 huajiao shenghui huajiao shiliaozhan huibian 华光永耀:1219华教盛会华教史料展汇编 (Cahaya pendidikan Cina kekal bersinar: Koleksi pameran sumber sejarah pendidikan Cina dalam temasya pendidikan Cina). Kuala Lumpur: Malaixiya huajiao dongshi lianhehui zonghui.

Ahmed Meah Baba Ahmed. 1992. Penaklukan Jepun: Suka duka di Georgetown. Kuala Lumpur: Media Indah Sdn. Bhd.

Azharudin Mohamed Dali. 2014. Sejarah perisikan di Malaysia. Kuala Lumpur: Dewan Bahasa dan Pustaka.

Cheah, B.K. 2000. Memory as history and moral judgement: Oral and written accounts of the Japanses Occupation of Malaya. In War and memory in Malaysia and Singapore, eds. P.P.H. Lim and D. Wong, 23-41. Singapore: Institute of Southeast Asian Studies.

2007. The "Black-out" syndrome and the ghosts of World War II: The war as a "Divisive Issue" in Malaysia. In Legacies of World War II in South and East Asia, ed. Koh, D.W.H., 47-59. Singapore: Institute of Southeast Asian Studies. https://doi.org/10.1355/9789812304575

. 2012. Red star over Malaya: Resistance and social conflict during and after the Japanese Occupation of Malaya, 1941-46. 4th ed. Singapore: NUS Press.

Chen, C. (Chen, D.) 陈充恩. 1939. Zhongling Xuexiao zhi shilue 锤灵学校之史略 [Sejarah ringkas Sekolah Chung Ling]. In Bincheng Yueshu Baoshe sanshi zhounian jinian tekan 槟城阅书报社三十周年纪念特刊 [Majalah Khas Cenderamata Ulang Tahun ke-30 Kesatuan Filomatik Pulau Pinang], Bincheng Yueshu Baoshe 槟城 阅书报社, A21-A22. Bincheng: Bincheng yueshu baoshe. 
Chen, D. 2003. In hiding. In Chen Chongen Xiaozhang yunan wushi zhounian jinian teji 陈充恩校长遇难五十周年纪念特辑 [Edisi Khas Peringatan Ulang Tahun Pengorbanan ke-50 Pengetua David Chen], ed. Yigu Chen Chongen Xiaozhang Jinian Zhuanji Bianweihui 已故陈充恩校长纪念专辑编委会，206-209. Bincheng: Zhongling Zhongxue Chen Chongen Xiaozhang Yunan Wushi Zhounian Jinian Gongweihui.

Chen, J. 陈敬文 (Tan, K.B.). 1997. Teqin gongzuo huiyilu 特勤工作回忆录 [Memoir tugas perisikan]. In Ouzhou yu Zhongguo zhilu 欧洲与中国之旅 [Melancong di Eropah dan China], Chen J. 陈敬文(Tan, K.B.) and Zeng, Q. 曾琼瑞(Chan, K.S.), 257-338. Bincheng: Chen jingwen, zeng qiongrui.

Chen, Q. mengimlakkan陈泉福口述, Zhang H. merekod 张汉忠笔录. 1997. Fenshu zhiwei jiu xiaoyou: ji yigu Zhongling xiaoyou Zeng Qianfu 焚书只为救校友: 记 已故锤灵校友曾谦福 [Bakar buku untuk menyelamatkan alumni: Memperingati alumni Chung Ling Zeng Qianfu] In Zhongling shisheng jinian wenji: jinian muxiao chuangxiao bashi zhounian 锤灵师生纪念文集: 纪念母校创校八十 周年 [Koleksi esei peringatan guru dan pelajar Chung Ling: Sempena ulang tahun ke-80 penubuhan sekolah], ed. Wen, Z. 温子开, 131-132. Pulau Pinang: Malaixiya zhongling xiaoyouhui zonghui \& Bincheng zhongling xiaoyouhui.

Chen, R. 陈荣春. 1997. Yi sawu niandai de Zhongling xuechao 忆卅五年代的锤灵学潮 [Mengingati protes pelajar Sekolah Chung Ling pada tahun 1935]. In Zhongling shisheng jinian wenji: Jinian muxiao chuangxiao bashi zhounian 锤灵师生纪 念文集: 纪念母校创校八十周年 [Koleksi esei peringatan guru dan pelajar Chung Ling: Sempena ulang tahun ke-80 penubuhan sekolah], ed. Wen, Z. 温子 开, 85-87. Pulau Pinang: Malaixiya zhongling xiaoyouhui zonghui \& Bincheng zhongling xiaoyouhui.

Chen, R. (Tan E. C.) 陈荣照. 2017. Bincheng Zhongling Zhongxue bainian shiji shangbian: Cunfeng huayu sishi nian 1917-1957 槟城锤灵中学百年史记上编: 春风化 雨四十年1917-1957 [Sejarah seratus tahun Sekolah Menengah Chung Ling 1: Sumbangan dalam pendidikan empat puluh tahun 1917-1957]. In Bincheng Zhongling bainian xiaoshi 槟城锤灵百年校史 [Sejarah seratus tahun Sekolah Chung Ling Pulau Pinang], ed. Chen, R. (Tan, E.C.) 陈荣照, 1-49. Kampung Baru: Binzhou zhongling zhongxue dongshihui.

Chen, S. (Tan, C.S.) 陈是呈. 2012. Sun Zhongshan jingshen zai Bincheng de chuancheng: yi Bincheng Yueshu Baoshe, Zhongling Xuexiao jinian huodeng he $<<$ Guanghua Ribao $>>$ baodao pingshu wei zhongxin (1927-1940) 孙中山精神在槟城的传 承: 以槟城阅书报社、锤灵学校纪念活动和《光华日报》报导评述为中心 (1927-1940) [Mewarisi semangat Sun Yat-sen di Pulau Pinang: Perbincangan fokuskan aktiviti peringatan Kesatuan Filomatik Pulau Pinang, Sekolah Chung Ling dan laporan dengan ulasan dalam "Kwong Wah Yit Poh" (1927-1940)]. Yatai yanjiu luntan 亚太研究论坛 [Asia-Pacific Forum], no. 57 (September): 135-164. 
. 2017. Bincheng Zhongling Zhongxue bainian shiji xiabian: Sanxiao yiti, zouxiang guoji: Zhongling yijiazi 1958- 2017 槟城锤灵中学百年史记下编: 三校一体, 走向国际：锤灵一甲子1958-2017 [Sejarah seratus tahun Sekolah Menengah Chung Ling 2: Tiga Sekolah sebagai satu, menuju ke dunia antarabangsa: Enam puluh tahun Chung Ling 1958-2017]. In Bincheng Zhongling bainian xiaoshi 槟城锤灵百年校史 [Sejarah seratus tahun Sekolah Chung Ling Pulau Pinang], ed. Chen, R. (Tan, E.C.) 陈荣照, 50-154. Kampung Baru: Binzhou zhongling zhongxue dongshihui.

Chew, D. and I. Lim. 1992. Sook Ching. Singapore: Oral History Department.

Chin, K.O. 1976. Malaya upside down. Singapore: Federal Publications.

Corfield, J. and R. Corfield. 2012. The fall of Singapore: 90 Days: November 1941February 1942. Singapore: Talisman Publishing Pte Ltd.

Fang, N. 方念祖. 1984. Bincheng dajianju ji Rikou duxing 槟城大检举及日寇毒刑 [Pemeriksaan besar-besaran di Pulau Pinang dan penyeksaan tentera Jepun). In Xinma Huaren kangri shiliao 1937-1945 新马华人抗日史料 1937-1945 [Malaysian Chinese resistance to Japan 1937-1945: Selected source materials), eds. Xu, Y. 许云樵 (Shu Y.-T.) and S. Cai蔡史君 (Chua, S.-K.), 509-512. Singapore: Wenshi chuban siren youxian gongsi.

File of Chan Yik King. n.d. File of Chan Yik King on education matters in Penang during the Japanese Occupation, 1942-1945. Perpustakaan Hamzah Sendut 1, Universiti Sains Malaysia. Microfilm: 1, 2078.

Han, J. (Han, K.F.) 韩觉夫. 1979. Wo dangle bianji yihou: jizhe shengya sanshinian xuji 我当了编辑以后: 记者生涯三十年续集 [Selepas saya menjadi editor: Sambungan tentang kisah kehidupan wartawan selama 30 tahun]. Bincheng: Binlang chubanshe.

Ho, H.L. 2009. Zaman pendudukan Jepun di Tanah Melayu, 1941-1945: Penentangan orang Cina melalui Malayan People's Anti Japanese Army (MPAJA). Malaysia Dari Segi Sejarah 37: 109-125.

Huang, S. 黄霜仁. 1947. Wo zenyang duguo nanguan? 我怎样渡过难关? [Bagaimana saya mengatasi kesulitan?]. In Bincheng Zhongling Zhongxue xunnan shisheng rongailu 槟城锤灵中学殉难师生荣哀录 [Rekod pengorbanan guru dan pelajar Sekolah Menengah Chung Ling Pulau Pinang], Zhongzhong Jinian Xunnan Shisheng Weiyuanhui Bianjizu 锤中纪念殉难师生委员会编辑组, 32-35. Bincheng: Zhongling zhongxue.

Huang, X. (Wong, S.K.) 黄贤强. 2008. Kuayu Shixue: jindai Zhongguo yu Nanyang Huaren yanjiu de xin shiye 跨域史学: 近代中国与南洋华人研究的新视野 [Pensejarahan merentasi rantau: Pandangan baru kajian China moden dan orang Cina Nanyang]. Xiamen: Xiamen daxue chubanshe.

Kratoska, P.H. 1998. The Japanese Occupation of Malaya: A social and economic history. St Leonards, NSW: Allen \& Unwin.

Kua, K.S. 1999. A protean saga: The Chinese schools of Malaysia. 3rd ed. Kajang: Dong Jiao Zong Higher Learning Centre. 
Li, B. 李宝镜. 1939. Guanghua Ribao shilue 光华日报史略 [Sejarah ringkas Kwong Wah Yit Poh]. In Bincheng Yueshu Baoshe sanshi zhounian jinian tekan 槟城阅书报 社三十周年纪念特刊 [Majalah khas cenderamata ulang tahun ke-30 Kesatuan Filomatik Pulau Pinang], Bincheng Yueshu Baoshe 槟城阅书报社, A11-A18. Bincheng: Bincheng yueshu baoshe.

Li, J. 李昫才 (Lee, K.C.). 1989. Zhuixun ziji de guojia: yige Nanyang huaren de xinlu licheng 追寻自己的国家: 一个南洋华人的心路历程 [Mengejar negara sendiri: Pengalaman seorang Cina di Nanyang]. Taibeishi: Yuanliu chuban shiye gufen youxian gongsi.

Lim, B.K. 1973/74. The Japanese Occupation in Penang, 1941-45. B.A. thesis, Department of History, University of Singapore.

Lim, K.S. 1999. Blood on the Golden Sands: The memoirs of a Penang family. Subang Jaya: Pelanduk Publications.

Lim, P.P.H. 1995. Memoirs of War in Malaya. In Malaya and Singapore during the Japanese Occupation, ed. P.H. Kratoska, 121-147. Singapore: The National University of Singapore.

. 2000. War and ambivalence: Monuments and memorials in Johor. In War and memory in Malaysia and Singapore, eds. P.P.H. Lim and D. Wong, 139-159. Singapore: Institute of Southeast Asian Studies.

Lin, H. (Lim, H.S.) 林惠祥. 1940. Banli benxiao zhi jihua jiqi shishi 办理本校之计划 及其实施 [Pelan dan pelaksanaan dalam pengurusan Sekolah Chung Ling]. Zhongling yuekan 锤灵月刊 [Majalah Bulanan Chung Ling] 1, no. 1 (Februari): $1-5$.

Mohamad Isa Othman. 1992. Pendudukan Jepun di Tanah Melayu 1942-1945: Tumpuan di negeri Kedah. Kuala Lumpur: Dewan Bahasa dan Pustaka \& Kementerian Pendidikan Malaysia.

Nanyang Binglangyu Zhongling Zhongxuexiao南洋槟榔屿锤灵中学校. 1926. Geji kecheng shugai各级课程述概 [Laporan kurikulum setiap tingkatan]. In Zhongling Zhongxue xiaokan: chuangkan hao 锤灵中学校刊: 创刊号 [Majalah Sekolah Menengah Chung Ling: Terbitan Perdana], 28-33. Bincheng: Nanyang binglangyu zhongling zhongxuexiao.

Ooi, K.G. 2010. Siri syarahan umum pelantikan profesor 2008/Bil. 2: "Baik, buruk, dan dahsyat": Pelbagai wajah peperangan dan akibatnya terhadap Asia Tenggara pada kurun kedua puluh. Pulau Pinang: Penerbit Universiti Sains Malaysia.

Penang Chung Ling High School-Board of Governors. n.d. Photo album. http:/www. chungling.edu.my/album.php?action=cat\&alcid=120\&page $=1 \#$. $($ accessd 7 April 2018).

Qi 期. 1938. Xiaoshi校史 [Sejarah sekolah]. In Nanyang Binglangyu Zhongling Zhongxue xiaokan: gaozhong diyijie biye jinian 南洋槟榔屿锤灵中学校刊: 高中第一届 毕业纪念 [Majalah Sekolah Menengah Chung Ling Pulau Pinang Nanyang: Cenderamata tamat pelajaran menengah atas sesi pertama], Zhongling Zhongxue 锤灵中学, 1-10. Bincheng: Zhongling zhongxue. 
Qi, Y. 起予. 1931. Zhongling Xuexiao zhi shilue 锤灵学校之史略 [Sejarah ringkas Sekolah Chung Ling]. In Bincheng Yueshu Baoshe ershisi zhounian jinian tekan 槟城阅书报社二十四周年纪念特刊 [Majalah khas cenderamata ulang tahun ke-24 Kesatuan Filomatik Pulau Pinang], Bincheng Yueshu Baoshe 槟城阅书报 社, 157-166. Bincheng: Bincheng yueshu baoshe.

Saravanamuttu Manicasothy. 2010. The Sara saga. Penang: Areca Books.

Suffian Mansor. 2009. Sejarah China moden. Kuala Lumpur: Penerbit Universiti Malaya. Tan, L.E. 1989. Whither Chinese education in Malaya: The controversy over Chung Ling High School, 1955-1957. Journal of the South Seas Society 44: 67-90. . 1997. The politics of Chinese education in Malaya, 1945-1961. Kuala Lumpur: Oxford University Press.

Tan, Y.S. 2014. Pendidikan Cina di Malaysia: Sejarah, politik dan gerakan perjuangan. Pulau Pinang: Penerbit Universiti Sains Malaysia.

Wang, K. (Wong, H.T.) 王慷鼎. 2017a. Gaozhan yuanzhu de shuangyu zhengce jiqi xiaoying 高瞻远瞩的双语政策及其效应 [Dasar dwibahasa yang berpandangan jauh dan kesannya]. In Bincheng Zhongling bainian xiaoshi 槟城锤灵百年 校史 [Sejarah seratus tahun Sekolah Chung Ling Pulau Pinang], ed. Chen, R. (Tan, E.C.) 陈荣照, 155-195. Kampung Baru: Binzhou zhongling zhongxue dongshihui.

.2017b. Dongjiaoxue sanwei yiti de KangRi Yundong (1937-1945) 董教学三位一 体的抗日运动 [Gerakan anti-Jepun tiga pihak iaitu jemaah pengurus, guru dan pelajar]. In Bincheng Zhongling bainian xiaoshi 槟城锤灵百年校史 [Sejarah seratus tahun Sekolah Chung Ling Pulau Pinang], ed. Chen, R. (Tan, E.C.) 陈荣 照, 218-301. Kampung Baru: Binzhou zhongling zhongxue dongshihui.

Wang, S. 王世毅. 1947. Zhongzhong jiaoyuan xunnanji 锤中教员殉难记 [Catatan pengorbanan guru Sekolah Menengah Chung Ling]. In Bincheng Zhongling Zhongxue xunnan shisheng rongailu 槟城锤灵中学殉难师生荣哀录 [Rekod pengorbanan guru dan pelajar Sekolah Menengah Chung Ling Pulau Pinang], Zhongzhong Jinian Xunnan Shisheng Weiyuanhui Bianjizu 锤中纪念殉难师生 委员会编辑组, 30. Bincheng: Zhongling zhongxue.

Wang, Y. 汪洋. 1947. Zhongling Zhongxue yuansheng xunnanji锤灵中学员生殉难 记 [Catatan pengorbanan guru dan pelajar Sekolah Menengah Chung Ling]. In Bincheng Zhongling Zhongxue xunnan shisheng rongailu 槟城锤灵中学殉难师 生荣哀录 [Rekod pengorbanan guru dan pelajar Sekolah Menengah Chung Ling Pulau Pinang], Zhongzhong Jinian Xunnan Shisheng Weiyuanhui Bianjizu 锤中 纪念殉难师生委员会编辑组, 23-29. Bincheng: Zhongling zhongxue.

Wong, L.F. 1973/74. The Japanese Occupation period in Penang, December 1941 to August 1945. Latihan ilmiah, Pusat Pengajian Ilmu Kemanusiaan, Universiti Sains Malaysia.

Wong, M. 2017. Voices that remain: Oral history accounts of the Japanese Occupation. Biblioasia 13(1): 56-59. 
Wu， T. 吴体仁. 1984. Lunxian shiqi de Bincheng jiaoyu 沦陷时期的槟城教育 [Pendidikan Pulau Pinang semasa Zaman Pendudukan Jepun]. In Xinma Huaren kangri shiliao 1937-1945 新马华人抗日史料 1937-1945 [Malaysian Chinese Resistance to Japan 1937-1945: Selected source materials], eds. Xu, Y. 许云樵 (Shu, Y.-T.) and Cai, S. 蔡史君 (Chua, S.-K.), 524-525. Singapore: Wenshi chuban siren youxian gongsi.

Xie, S. 谢松山. 1984. Jiang Huangxi de cansi 江晃西的惨死 [Kematian tragis Jiang Huangxi]. In Xinma Huaren kangri shiliao 1937-1945 新马华人抗日史料 1937-1945 [Malaysian Chinese Resistance to Japan 1937-1945: Selected source materials], eds. Xu, Y. 许云樵 (Shu, Y.-T.) and Cai, S. 蔡史君 (Chua, S.-K.), 517-518. Singapore: Wenshi chuban siren youxian gongsi.

Xie, Y. 谢幼青. 1947. Shoujun cuican Zhongzhong de tongyan 兽军摧残锤中的痛 言 [Kesakitan memaklumkan tentang Sekolah Menengah Chung Ling yang dimusnahkan oleh tentera ganas]. In Bincheng Zhongling Zhongxue xunnan shisheng rongailu 槟城锤灵中学殉难师生荣哀录 [Rekod Pengorbanan guru dan pelajar Sekolah Menengah Chung Ling Pulau Pinang], Zhongzhong Jinian Xunnan Shisheng Weiyuanhui Bianjizu 锤中纪念殉难师生委员会编辑组, 22. Bincheng: Zhongling zhongxue.

Xu, S. (Khaw, S.L.) 许生理 memaklum, Wang Z. 王子珊mencatat. 1926. Benxiao choubei zhi jingguo本校筹备之经过 [Proses persediaan untuk menubuhkan sekolah kami]. In Zhongling Zhongxue xiaokan: chuangkan hao 锤灵中学校刊: 创刊号 [Majalah Sekolah Menengah Chung Ling: Terbitan perdana], Nanyang Binglangyu Zhongling Zhongxuexiao南洋槟榔屿锤灵中学校, 1-9. Bincheng: Nanyang binglangyu zhongling zhongxuexiao.

Yang, H. 杨汉翔. 1931. Zhonghua Minguo kaiguo qianhou zhi benshe gemingshi 中华民 国开国前后之本社革命史 [Sejarah revolusi kesatuan kami sebelum dan selepas penubuhan republik]. In Bincheng Yueshu Baoshe ershisi zhounian jinian tekan 槟城阅书报社二十四周年纪念特刊 [Majalah khas cenderamata ulang tahun ke-24 Kesatuan Filomatik Pulau Pinang], Bincheng Yueshu Baoshe 槟城阅书报 社, 1-108. Bincheng: Bincheng yueshu baoshe.

Ye, G. 叶国祯, ed. 2008. Zhongguo Tongmenghui de geming ceyuandi: Bincheng Sun Zhongshan Jinian Guan jianjie 中国同盟会的革命策源地: 槟城孙中山纪念馆 简介 [Tempat asal revolusi Perikatan Revolusioner China: Pengenalan kepada Pusat Memorial Sun Yat-sen Pulau Pinang]. Bincheng: Bincheng sun zhongshan jinianguan.

Ye, Z. (Yeap, C.L.) 叶钟铃. 1993. Bincheng Huaqiao Zhongxue xiaoshi 槟城华侨中学校 史 [Sejarah Sekolah Menengah Huaqiao Pulau Pinang]. Zhongjiao xuebao 中教 学报 [Majalah Guru Sekolah Menengah] 19: 65-76.

. 2009. Bincheng Zhongling Zhongxue shigao (1917-1957) 槟城锤灵中学史稿 (1917-1957). [Sejarah Sekolah Menengah Chung Ling (1917-1957)]. Xinjiapo: Huayiguan.

Yeoh, B.S.A. and Kamalini Ramdas. 2000. Remembering darkness: Spectacle, surveillance and the spaces of everyday life in Syonan-to. In War and memory in Malaysia and Singapore, eds. P.P.H. Lim and D. Wong, 160-185. Singapore: Institute of Southeast Asian Studies. 
Yi, T. 依藤. 1957. Binan jiehuilu 彼南劫灰录 [Rekod kecelakaan Pulau Pinang]. Bincheng: Bincheng zhongling zhongxue.

Zhang, J. 张家荣. 1947. Mudu de "Yangzhou Shiri" 目睹的 “扬州十日 [Pembunuhan "sepuluh hari Yangzhou" yang disaksi]. In Bincheng Zhongling Zhongxue xunnan shisheng rongailu 槟城锤灵中学殉难师生荣哀录 [Rekod pengorbanan guru dan pelajar Sekolah Menengah Chung Ling Pulau Pinang], Zhongzhong Jinian Xunnan Shisheng Weiyuanhui Bianjizu 锤中纪念殉难师生委员会编辑组, 36. Bincheng: Zhongling zhongxue.

Zhang, S. (Teoh, S.K.) 张少宽. 2004. Sun Zhongshan yu Bineng Huiyi: cedong Guangzhou San Erjiu zhi Yi 孙中山与庇能会议: 策动广州三、二九之役 [Sun Yat-sen dan Mesyuarat Pulau Pinang: Melancarkan revolusi bersenjata Guangzhou 29 Mac]. Bincheng: Nanyang tianye yanjiushi.

Zheng, L. (Tay, L.S.) 郑良树. 1999. Malaixiya huawen jiaoyu fazhanshi: dier fence 马 来西亚华文教育发展史: 第二分册 [Sejarah perkembangan pendidikan Cina Malaysia: Jilid 2]. Kuala Lumpur: Malaixiya huaxiao jiaoshihui zonghui.

Zhongzhong Jinian Xunnan Shisheng Weiyuanhui Bianjizu 锤中纪念殉难师生委员会编 辑组. 1947. Bincheng Zhongling Zhongxue xunnan shisheng rongailu 槟城锤灵 中学殉难师生荣哀录 [Rekod pengorbanan guru dan pelajar Sekolah Menengah Chung Ling Pulau Pinang]. Bincheng: Zhongling zhongxue.

Zhuang, X. 庄锡号. 1997. Zhongling Guanghui lishi huigu: Zhongling zhisheng huanqile Malaixiya de duli yundong 锤灵光辉历史回顾: 锤灵之声唤起了马来西亚 的独立运动 [Imbasan sejarah kegemilangan Chung Ling: Bunyi Chung Ling membangkitkan gerakan kemerdekaan Malaysia]. In Zhongling shisheng jinian wenji: jinian muxiao chuangxiao bashi zhounian 锤灵师生纪念文集: 纪念母校 创校八十周年 [Koleksi esei peringatan guru dan pelajar Chung Ling: Sempena ulang tahun ke-80 penubuhan sekolah], ed. Wen, Z. 温子开, 77-80. Pulau Pinang: Malaixiya zhongling xiaoyouhui zonghui \& Bincheng zhongling xiaoyouhui. 